Amasya Ilahiyat Dergisi - Amasya Theology Journal

ISSN 2667-7326 | e-ISSN 2667-6710

Haziran / June 2021, 16: 89-124

\title{
İslâm Aile Hukukunda Boşanma Yetkisinin Kötüye Kullanılmasının Hükmü ve Hukukî Sonucu
}

\author{
Mehmet Aziz YAŞAR \\ Doç. Dr., Mardin Artuklu Üniversitesi, İslami İlimler Fakültesi, \\ İslam Hukuku Anabilim Dalı \\ Associate Professor, Mardin Artuklu University, Faculty of İslamic Sciences, \\ Department of Islamic Law \\ Mardin, Turkey \\ ya-ar19801@hotmail.com \\ orcid.org/0000-0002-4677-1017
}

\section{Makale Bilgisi / Article Information}

Makale Türü / Article Types: Araştırma Makalesi / Research Article

Geliş Tarihi / Received: 7 Ocak / January 2021

Kabul Tarihi / Accepted: 7 Nisan / April 2021

Yayın Tarihi / Published: 30 Haziran / June 2021

Yayin Sezonu / Pub. Date Season: Haziran / June

Sayı / Issue: 16 Sayfa / Pages: 89-124

Atıf / Cite as: Yaşar, Mehmet Aziz. "İslâm Aile Hukukunda Boşanma Yetkisinin Kötüye Kullanılmasının Hükmü ve Hukukî Sonucu [The Judgment and Legal Consequence of Abuse of Divorce Authority in Islamic Family Law]". Amasya IIlahiyat Dergisi-Amasya Theology Journal 16 (June 2021): 89-124.

https://doi.org/10.18498/amailad.855823.

İntihal / Plagiarism: Bu makale, en az iki hakem tarafından incelendi ve intihal içermediği teyit edildi. / This article has been reviewed by at least two referees and scanned via a plagiarism software.

Copyright @ $\odot$ Published by Amasya Üniversitesi, İlahiyat Fakültesi / Amasya University, Faculty of Theology, Amasya, 05100 Turkey. All rights reserved. https://dergipark.org.tr/amailad. 
90 | M. A. YAŞAR / İslâm Aile Hukukunda Boşanma Yetkisinin Kötüye Kullanılmasının Hükmü ve Hukukî Sonucu

\section{The Judgment and Legal Consequence of Abuse of Divorce Authority in Islamic Family Law}

\section{Abstract}

Great importance is attached to marriage in Islam. Various measures have been taken to ensure the continuation of this establishment. However, in some cases, the relationship between spouses can be unbearable. At this point, divorce has been legitimized as a solution. Divorce right/authority is given to the husband in principle, especially to ensure the balance of blessing and burden, but this authority can also be shared with the woman under certain conditions. This authority should be applied as the last solution when the marital life turns into suffering for the spouses, but it may also be used by the spouses as a means of harming the other party. At this point, Islamic jurists examined both the religious and legal dimensions of such malevolent behaviors and tried to prevent this by specifying various provisions based on the relevant texts. In this framework, firstly, the concept of "et-ta'assuf fi't-talak" used by contemporary Islamic jurists for this kind of divorce and the important specification and criteria sought in its realization were tried to be explained. Afterwards, the legal provision of this kind of divorce/separation was examined together with the different approaches of the fukahâ (a person who has advanced knowledge of fiqh in the science of fiqh enough to express opinions). In addition, the fact that what is essential in talaq, which is at the center of their different approaches, is permissibility or haram is also briefly discussed. Another important issue included in the study is the legal consequence of the divorce/separation performed by the spouses for the sole purpose of harming the other party without any sharia reason, which is called "abuse of right". In this context, firstly, the criteria that play a fundamental role in talking about the phenomenon of "abuse of right" were briefly mentioned. Then, the legal consequences of divorcing the wife or the separation of the woman from her husband, who suffered from the disease of death, referred to as in the literature "death disease or feared disease", was explained. The different views of the Fukahâ on this and the factors that affect the formation of these different views have been examined. In addition, in the study, the legal consequences of the husband divorcing his wife for an insignificant purpose such as the realization of another marriage without a justifiable reason considered as abuse of right, or the woman's separation from her husband with the rights granted to her were also discussed. 
M. A. YAŞAR / The Judgment and Legal Consequence of Abuse of Divorce Authority in Islamic

Family Law | 91

In the examination, it is concluded that it is not permissible to divorce only to harm the other party or to gain an insignificant personal benefit. And that the husband or wife who committed this should be treated in violation of this bad purpose and that it would be more appropriate to make a deterrent decision. Accordingly, designating an heir to the wife who the death-sick husband divorced without a legitimate reason, -without restricting her inheritance to the end of the iddah or marrying another person; and designating an heir to the husband who the wife on her deathbed divorced without any reasonable grounds by the tefvîz method, without his right of inheritance is restricted by any reason would be more suitable. Likewise, giving the husband the least from the hul cost or the inheritance in the event that the woman who suffers death leaves her husband with this method by keeping the hul cost high in order to harm her other heirs; and in the event that the woman takes such a way to deprive her husband of the inheritance, it will be more appropriate to give her husband the most of the hul price or inheritance. Again, in the event that the other party suffers material or moral damage due to the divorce of the husband, who is in good health without a legitimate reason, or the divorce of the wife from her husband, it has come to the conclusion that it would be more beneficial in terms of the result to make the person who caused the damage pay the compensation.

Keywords: İslamic Law, Family, Divorce, Wife, Husband.

\section{İslâm Aile Hukukunda Boşanma Yetkisinin Kötüye Kullanılmasının Hükmü ve Hukukî Sonucu}

Öz

İslâm dininde evlilik müessesine büyük önem atfedilmiştir. Bu müessesinin devamını temine yönelik çeşitli tedbirler alınmıştır. Ancak bazı durumlarda eşler arasındaki ilişki zedelenip yaşanmaz bir keyfiyet alabilmektedir. Bunun çözüm yolu olarak boşanma meşru kılınmıştır. Bilhassa nimet-külfet dengesinin sağlanması için prensip olarak kocaya verilen boşanma hakkı/yetkisi belli şartlar çerçevesinde kadınla da paylaşılabilmektedir. Mezkûr yetkiye ise evlilik hayatı eşler için acı ve ıstırap haline dönüştüğünde son çözüm olarak başvurulması gerekirken eşlerden bunu, karşı tarafa zarar verme aracı olarak kullanan da olabilmektedir. Bu noktada İslâm hukukçuları, bu tür art niyetli davranışların hem dinî hem de hukukî boyutlarını, incelemiş ve ilgili naslardan hareketle çeşitli hükümler belirterek bunun önüne geçmeye çalışmışlardır. 
92 | M. A. YAŞAR / İslâm Aile Hukukunda Boşanma Yetkisinin Kötüye Kullanılmasının Hükmü ve Hukukî Sonucu

Çalışmamızda geçerli bir neden olmaksızın kocanın eşini boşamasının veya kadının hul' veya tefvîz yoluyla kocasından ayrılmasının dinî hükmü ve hukukî sonucu ele alınmıştır. Bu çerçevede önce çağdaş İslâm hukukçular tarafından bu tarz boşanma için kullanılan "et-ta'assuf fi't-talak" kavramı ve bunun gerçekleşmesinde aranan önemli özellik ve kriterler izah edilmeye çalışılmıştır. Sonrasında bu türden boşanmanın/ayrılmanın fıkhî hükmü, fukahânın buna yönelik farklı yaklaşımlarıyla birlikte irdelenmiştir. Bunun yanı sıra fukahânın konuya ilişkin farklı yaklaşımlarının merkezinde yer alan talâkta aslolan mubahlık veya haramlık olduğu hususu da kısa bir şekilde ele alınmıştır. Çalışmada yer verilen diğer önemli bir konu, eşlerin "hakkın kötüye kullanılması" olarak tabir edilen her hangi bir şer'î gerekçe olmadan sırf karşı tarafa zarar vermek amacıyla gerçekleştirdikleri boşanmanın/ayrılmanın hukukî sonucudur. Bu bağlamda da önce "hakkın kötüye kullanılması" olgusundan söz edilebilmesinde temel rol oynayan kriterlerden kısaca söz edilmiştir. Ardından literatürde "maraz-1 mevt/ölüm hastalığı veya maraz-i mahûf/korkulan hastalık" ifadeleriyle anılan ölüm hastalığına yakalanan kocanın hanımını boşamasının veya kadının kocasından ayrılmasının hukukî sonucu açıklanmıştır. Fukahânın buna ilişkin farklı görüşleri ve bu farklı görüşlerin oluşmasında etkili olan faktörler incelenmiştir. Ayrıca çalışmada hakkın kötüye kullanılması olarak değerlendirilen haklı bir gerekçe olmaksızın, başka bir evliliğin gerçekleştirilmesi gibi önemsiz bir amaç uğruna kocanın eşini boşaması veya kadının kendisine tanınan haklarla kocasından ayrılmasının hukukî sonucu da tartışılmıştır.

Yapılan incelemede karı veya kocanın karşı tarafa zarar vermek amacıyla gerçekleştirdiği ayrılmanın haram bir davranış olarak görülmesi daha tercihe şayan bulunmuştur. Diğer taraftan bunu gerçekleştiren karı veya koca ile bu kötü amacına aykırı olarak muamele edilmesi gerektiği ve bundan caydırıcı bir hükmün konulması daha doğru olacağı kanaatine varılmıştır. Buna göre ölüm hastası kocanın, meşru bir gerekçe bulunmaksızın boşadığı karısının, -miras hakkı iddetin bitmesiyle veya başka biriyle evlenmesiyle sınırlandırılmaksızınmirasçı kılınması; buna mukabil ölüm döşeğinde olan karının, haklı bir gerekçe olmaksızın tefvîz yöntemiyle ayrıldığı kocasının -miras hakkı herhangi bir durumla kayıtlanmaksızın- mirasçı yapılması hakkaniyete daha uygun düşecektir. Aynı şekilde ölüm hastası kadının, diğer mirasçılarına zarar vermek amacıyla hul' bedelini yüksek tutarak bu yöntemle kocasında ayrılması durumunda kocaya hul' bedelinden veya mirastan en az olanın ödenmesi; buna karşı kadının kocasını mirastan mahrum etmek amacıyla böyle bir yola tevessül 
M. A. YAŞAR / The Judgment and Legal Consequence of Abuse of Divorce Authority in Islamic Family Law | 93

etmesi halinde ise kocasina, hul' bedelinden veya mirastan en fazla olanin verilmesi daha isabetli olacaktır. Yine meşru bir neden olmaksızın sağlıklı olan kocanın eşini boşaması veya sağlıklı olan karının kocasından ayrılması nedeniyle karşı tarafın maddî veya manevî bir zarara uğraması halinde zarara sebebiyet verene tazminatın ödettirilmesinin netice bakımından daha yararlı olacağ1 kanaati hâsıl olmuştur.

Anahtar Kelimler: İslam Hukuku, Aile, Boşanma, Karı, Koca.

\section{Giriş}

İslâm dini, toplumun temelini teşkil eden aile müessesesine; dolayısıyla da ailenin kurulmasında ilk evreyi oluşturan ve insan soyunun devamına katkı sağlayan yegâne meşru' ilişki olan evlilik olgusuna büyük önem vermiştir. Nitekim evlilik konusuna ilişkin belli başlı düzenlemeler doğrudan Kur'an ve sünnet tarafından yapılmış

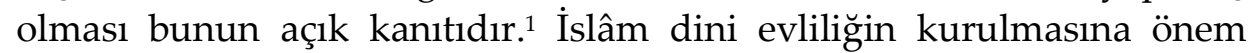
verdiği kadar sağlıklı bir şekilde sürdürülmesini istemiş ve makul bir gerekçe bulunmadıkça sona erdirilmesini tasvip etmemiştir. Eşlerin birlikteliklerini karşılıklı saygı ve sevgi içinde idame etmelerini teşvik etmiş ve bu birlikteliğin bozulmaması için bazı tedbirler almıştır. ${ }^{2} \mathrm{Bu}$ bağlamda da eşler arasında yaşanan geçimsizliklerin çözümü için en iyi yöntemin sulh olduğu ifade edilmiştir. ${ }^{3}$ Geçimsizliğin son bulmaması durumunda eşlerin ailelerinden seçilecek hakemlerin arabuluculuk yapmaları önerilmiştir. ${ }^{4}$ Bunun da fayda etmemesi ve karı-koca arasındaki ilişki yaşanmaz bir keyfiyette dönüşmesi halinde ise son çözüm olarak boşanma yolu meşru kılınmıştır. Boşanma olayı ise tek seferde evlilik bağını sona erdirecek bir çözüm biçiminde değil, eşlerin

1 el-Bakara, 2/228, 233; en-Nisâ, 4/3, 4, 34; et-Talâk 65/6-7; Ebu Abdullah Muhammed İbn Mâce, es-Sünen (b.y.: Dâru İhyâi'l-Kütübi'l-'Arabî, ts.), 1/604, 605, 606 (No. 1879, 1880, 1881).

2 Metin Yiğit, "İslam Hukuku'nda Boşanmayı Önleyici Tedbirler”, Dicle Üniversitesi İlahiyat Fakültesi Dergisi 19/1 (2017), 4; İbrahim Yılmaz, "İslâm Aile Hukukunda Boşanmaları Önleyici Bir Tedbir Olarak Tahkîm Müesseselerine Hukukî İşlerlik Kazandırılması", Turkish Studies 12/10 (2017), 333-334, 338-339.

3 en-Nisâ, 4/128.

4 en-Nisâ, 4/25, 4/128. 
94 | M. A. YAŞAR / İslâm Aile Hukukunda Boşanma Yetkisinin Kötüye Kullanılmasının Hükmü ve Hukukî Sonucu

düşünme fırsatını bulmaları maksadıyla farklı zamanlar ve mekânlarda gerçekleştirilmek üzere üç ayrı boşama şeklinde düzenlenmiştir. ${ }^{5}$ Bununla beraber Boşanma olgusu helâl şeyler içerisinde Allah katında en sevimsiz şey olarak kabul edilmiştir. ${ }^{6}$

İslâm aile hukukunda özellikle "nimet külfet dengesi"nin sağlanması amaciyla boşanma yetkisi doğrudan kocaya verilmiştir. Bu bağlamda nikâh akdinde kadına verilen mehir, evlilik süresince kadının nafakası, iddet nafakası ve meskeni, temas gerçekleşmeden boşanan kadına verilen maddî destek (mut'a) gibi evlilik ilişkisine terettüp eden maddi külfetlerin tamamı kocaya yüklenmiştir. $\mathrm{Bu}$ tür malî masraflardan sorumlu olduğunun bilincinde olan kocanın evliliğin bozulmaması hususunda daha temkinli davranacağı ve boşanma konusunda fevrî hareket etmeyeceği açıtır. Bu ise ciddi bir sebep ortaya çıkmadıkça boşanmanın gerçekleşmeyeceğinden; dolayısıyla da keyfî boşanmaların önüne geçileceğinden önem arz etmektedir. ${ }^{7}$ Ancak hemen belirtmeliyiz ki boşanma yetkisi ilke olarak kocaya verilen bir hak olsa da bu hak devredilemez bir yetki ve kadının büsbütün kocaya mahkûm bırakılma şeklinde anlaşılmamalıdır. Çünkü belli şartalar çerçevesinde bu yetki, nikâh akdi sırasında veya sonrasında kadına verilebilmekte ve kadın bunu kullanabilmektedir. Kadının bu yetkiye sahip olması ise şu iki yöntemle mümkündür: Birincisi, kadının belli bir bedel karşılığında kendisini kocasından boşamasıdır. Bu tarz boşanma literatürde "hul" veya "muhâle'a" olarak ifade edilmektedir. ${ }^{8}$ İkincisi, kocanın nikâh akdi öncesinde veya akit sırasında ya da sonrasında kadına boşama yetkisini vermesidir. Kadına verilen bu tür boşanma

5 el-Bakara, 2/229.

6 Süleyman b. el-Aş`as Ebû Dâvûd, es-Sünen (Beyrut el-Mektebetü'l-'Asriyye, ts.), 2/255 (No. 2178); Muhammed Latif Altun, Aile Hukuku Özelinde Hanefi ve Evzââ Mezheplerinin Mukayesesi (Ankara: İlahiyat Yayınları, 2020), 210.

7 Abdulvehhâb Hallâf, Ahkâmü'l-ahvâli'ş-şahșiyye fi'ş-şerî'ati'l-İslâmiyye (Kahire: Dâru'lKütübi'l-Misriyye, 1357/1938), 133.

8 Abdullah b. Ahmed İbn Kudâme, el-Muggnh, thk. Abdullah b. Abdilmuhsin Abdulfettah Muhammed (Riyad: Dâru 'Âlemi'l-Kütüb, 1406, 1412, 1417/1986, 1992, 1997), 7/323; Yahya b. Şeref en-Nevevî, Ravdatü't-țâlibîn ve 'umdetü'l-müftîn, thk. Zuhayr eş-Şâvîş (Beyrut: el-Mektebü'l-İslâmî, 1412/1991), 7/374; Fahrettin Atar, "Muhâlea", Türkiye Diyanet Vakfı İslâm Ansiklopedisi (Ankara: TDV Yayınları, 2005), 30/399. 
M. A. YAŞAR / The Judgment and Legal Consequence of Abuse of Divorce Authority in Islamic Family Law | 95 yetkisi ise "Tefvîzu't-talâk" olarak tabir edilmektedir. Kadın, kocasının veya başkasının izin ve rızasına ihtiyaç duymaksızın bu yetki devriyle arzuladığı vakitte tek taraflı iradesiyle kendisini boşayabilmektedir. ${ }^{9}$

Esasında boşanma, karı ve koca arasında geçimsizliğin had safhaya ulaşıp artık onların evlilik birlikteliklerini sürdürmeleri imkânsızlaştığı durumda şâri` tarafından bir çözüm yolu olarak kocaya doğrudan, karıya ise dolaylı olarak verilen meşru bir haktır/yetkidir. İslâm hukukunda bu yetkinin kullanımıyla ilgili gereken düzenlemeler yapılmış ve kötüye kullanılmasının önüne geçilmeye çalışılmıştır. Buna rağmen karı ve kocanın kendisine verilen bu hakkı meşru olmayan amaçlar için kullandığı müşahede edilmektedir. İşte bu çalışmada eşlerin sözü edilen bu hakkı asıl amacı dışında kullanmalarının hükmü ve hukukî sonuçları irdelenecektir.

\section{Hükmü}

1. Eşlerin Boşama/Ayrılma Yetkilerini Kötüye Kullanmalarının

Boşanma yetkisinin kötüye kullanılması olgusu çağdaş İslâm hukukçular tarafindan "et-ta'assuf fi't-talak" tabiriyle ifade edilmektedir. Burada sözü edilen boşanmanın hükmüne geçmeden önce bu kavramın mahiyetini izah etmeye çalışacağı.

\section{Mahiyeti \\ 1.1. Boşanma Yetkisinin Kötüye Kullanılmasının (Ta'assufun)}

"Talâkta ta'assuf" olarak nitelendirilen eşlerin boşanma yetkilerini kötüye kullanmalarının hükmüne geçmeden önce bunun çerçevesinin belirlenmesi gerekir. Çünkü bir olayın fıkhî hükmünün belirlenmesi ancak onu, türlerinden ayıran mahiyetini ve kriterlerini doğru bir biçimde bilmekle mümkündür. Sözlükte ta'assuf, amaçsız ve rehbersiz bir şekilde yola koyulmak, yoldan sapmak, zulmetmek, insafsızca davranmak gibi manalara gelmektedir. ${ }^{10}$ Istılahı anlamda ise ta'assufun, klasik fıkıh kaynaklarında çok sayıda uygulaması bulunmasına

9 Muhammed b. Ahmed eş-Şirbînî, Muğni'l-muhtâç ilâ ma'rifeti maâni elfâzi'l-Minhâc (Beyrut: Dâru'1 Kütübi'l-'Illmiyye, 1415/1994), 4/465; Bedri Aslan, "Boşanma Yetkisi Hakkında Yapılan Tartışmalar", Uluslararası Sosyal Araştırmalar Dergisi 11/55 (2018), 919.

10 Muhammed b. Mukrim İbn Manzûr, Lisânü'l-'Arab (Beyrut: Dâru Sadr, 1414/1994), "asf", 9/245-246. 
96 | M. A. YAŞAR / İslâm Aile Hukukunda Boşanma Yetkisinin Kötüye Kullanılmasının Hükmü ve Hukukî Sonucu

rağmen ${ }^{11}$ bir terim olarak tanımına yer verilmemiştir. Onun tanımı son dönem İslâm hukukçularına aittir. Muasır hukukçular tarafından yapılan ta'assufun farklı tanımları arasında ise Fethî ed-Dirînî'nin şu tanımı kabule şayan görünmektedir: "Kişinin aslı itibariyle hukuken izin verilmiş olan bir yetkiyi şâri'in amacına aykırı kullanmasıdır."12 Sözlükte "serbest bırakmak, salı vermek, bağını çözmek" anlamlarında kullanılan talâkın terim manasıyla ilgili yapılan çeşitli tanımlar arasında Şâfiî fakîh Hatîb eş-Şirbînî'nin (öl. 977/1570) şu tanımını uygun bulmaktayı: "Talâk veya benzeri lafızlarla nikâh akdinin bozulmasıdır."13 Netice itibariyle talâkta ta'assuf olgusunu şu şekilde tanımlayabiliriz: "Karı veya kocanın meşru olan boşanma yetkisini şâri'in amacına aykırı kullanmasıdır." Bir kısım fukahânın de belirtiği gibi boşanma, asıl itibarıla istenmeyen bir tasarruf olmakla beraber ${ }^{14}$ eşler arasında uyuşmazlıkların giderilmesinin imkânsız bir hal aldığı ve birlikteliklerinin adeta istırap ve çileye dönüştüğü durumlarda şâri' tarafından mubah kılınan bir çözümdür. Bu çözümün uygulanmasında ise koca doğrudan karı ise dolaylı olarak yetkilendirilmiştir. Hâl böyleyken karı veya koca, eşini mirastan mahrum bırakmak veya ona bir zarar vermek amacıyla kendisine verilen bu yetkiyi kullanırsa şâri' in amacına ters hareket etmiş olur ve meşru bir hakkı kötüye kullanmış sayılir.

Meşru bir hakkın kötüye kullanılmasından söz edebilmek için muasır bazı araştırmacılar tarafından birtakım kriterler ileri sürülmüştür. Söz konusu kriterleri ise şu maddelerde toplayabiliriz:

a) Boşanmada zarar verme amacının güdülmesi: Yukarıda da temas edildiği üzere evlilik akdinin son bulmasından ibaret olan boşanma, başvurulabilecek en son çözüm olmalıdır. Böylece koca

11 Muhammed b. İdrîs eş-Şâfiî, el-Ümm (Beyrut: Dâru'l-Ma'rife, 1410/1990), 5/270-271; İbn Kudâme, el-Muginnî, 6/396.

12 Fethî ed-Dirînî, Naẓariyyetü't-ta'assuf fî̀ isti'mâli'l-hak fi'l-fikhi'l-İslamî (Beyrut: Müessesetü'r-Risâle, 1408/1988), 87; Mehmet Selim Aslan, "İslam Hukukunda 'Ta'assuf Kavramı ve Hükümlere Etkisi", EKEV Akademi Dergisi - Sosyal Bilimler 20/67 (2016), 208.

13 Şirbînî, Muğni'l-muhtâç̧, 4/455.

14 Ahmed b. Abdulhalim İbn Teymiyye, el-Fetâve'l-kubrâ (b.y.: Dâru'l-Kütübi'l-'İlmiyye, 1408/1997), 3/250; Muhammed Emîn b. Ömer İbn 'Âbidîn, Reddü'l-muhtâr 'ale'ddürri'l-muhtâr ve hâşiyeti İbn 'Âbidîn (Beyrut: Dâru'l-Fikr, 1412/1992), 3/228. 
M. A. YAŞAR / The Judgment and Legal Consequence of Abuse of Divorce Authority in Islamic

Family Law | 97

boşanma yetkisini, kadın ise tefvîz hakkını sırf başkasına zarar vermek amacıyla kullanırsa meşru olan bir hakkı kötüye kulanmış olur. Bu maddeye ölüm döşeğinde bulunan karı veya kocanın karşı tarafı mirastan mahrum bırakmak amacıyla boşama/ayrılma işlemini gerçekleştirmesi olayı örnek olarak gösterilebilir.

d) Boşanmadan amaçlanan maslahatın onun sonucuna terettüp eden maslahata göre çok daha az olması: Karı veya kocanın sırf başkasıyla evlenmek için boşanma yetkisini kullanarak evlilik akdini bitirmesi buna örnek verilebilir.

c) Boşanmadan hedeflenen şahsî maslahatın büyük bir zarara sebebiyet vermesi: Örneğin meşru bir sebep olmadan eşini boşananın amaçladığı menfaat ne kadar büyük olsa da bir yuvanın dağılmasından kaynaklanan bir zarara karşıllı gelmez. ${ }^{15}$

Görüldüğü üzere ta'assuf talâkın gerçekleşmesinde genellikle karı veya kocanın karşı tarafa zarar verme veya büyük bir zarara karşılık değersiz bir maslahatın elde etme gayesi rol oynamaktadır. Bu ise şâri'in eşler arasındaki ilişkilerin çıkmaza girdiği durumda bir çözüm olarak sunduğu boşanmadan amaçlanan gayeye ters düşmektedir. ${ }^{16}$ Daha öz bir ifadeyle boşanma tasarrufu, asıl itibarıyla meşru kılınan bir hak olsa da başkasına zarar verme aracına dönüştüğünde şâri' in asıl amacına ters düşer ki bu da hukuken verilen bir yetkinin kötüye kullanılmasından ibarettir. ${ }^{17}$ Konuyla ilgili ihtilaf da bu noktadan kaynaklanmaktadır.

\subsection{Boşanma Yetkisinin Kötüye Kullanılmasının Hükmü}

Nikâh akdinin bitirilmesi için boşanmanın meşru bir tasarruf olduğu hususunda fukahâ hemfikirdirler. ${ }^{18}$ Boşanmanin meşruiyetine delil olarak genelde "Boşama iki defadır. Sonrası ya iyilikle tutmak ya da güzellikle serbest bırakmaktır."19 meâlindeki âyet ve bu minvalde varid

15 Bk. Sümeyye Abdulazîz, Tațbîku nazariyyeti't-ța'assuf fî isti'mâli'l-hak fî ba'di mesâili'lahvôali'ş-şahșiyye (Buyra: Câmi'atu Aklî Mohand Olhâc, Yüksek Lisans Tezi, 2016), 3234; Eymen Mustafa ed-Debbâğ, "et-Ta'assuf fi'ț-țalâk" , Mecelletu Câmi'atu'l-Aksâ 12/1 (2014), 70-71.

16 Ali Abdullah el-'Avn, "et-Ta'assuf fi'ț-țalâḳ ve'l-ḥukûựül-mütarattab 'aleyh", Dirâsâtu 'Ulûmi'ş-Şerî'a ve'l-Kânûn 43/2 (2016), 645.

17 Aslan, "İslam Hukukunda 'Ta'assuf Kavramı”, 208.

18 İbn Kudâme, el-Muġnî, $7 / 363$.

19 el-Bakara, 2/229. 
98 | M. A. YAŞAR / İslâm Aile Hukukunda Boşanma Yetkisinin Kötüye Kullanılmasının Hükmü ve Hukukî Sonucu

olmuş diğer âyet ve hadisler gösterilmektedir. ${ }^{20}$ Ancak fukahâ, boşanmanın asıl itibariyle mubah olup olmadığı hususunda iki farklı görüş ortaya koymuşlardır.

a) Bir kısım fukahâya göre boşanmada aslolan mubahlıktır. İbnü'1 Münzir (öl. 318/930 [?]) bu konuda şunları kaydetmiştir:

“Yüce Allah, 'Ey Nebî! Eşlerinizi boşamak istediğinizde iddetleri süresinde boşayın ve onların iddetlerini sayın.'21 buyurarak boşanmayı helal kılmıştır. Yine Hz. Peygamber'in (s.a.v.) de Hz. Ömer'in kendisine oğlu Abdullah'ın boşanma meselesini açınca 'Temizlendiğinde istediği zaman boşayabilir.'²2 dediği tespit edilmiştir. Görüldüğü üzere kitap ve sünnet boşanmanın mubah olup mahzur olmadığını göstermektedir.

Zaten boşanmanın helal olduğuna delalet eden birçok haber bulunduğu halde onu haram kılacak herhangi bir haber tespit edilmemiştir." 23

Kurtubî (öl. 671/1273) de "Kitap, sünnet ve ümmetin icmâ1, boşanmada aslolan mubahlık olduğunu göstermektedir." ${ }^{24}$ diyerek bu görüşü tercih etmiştir. Aynı şekilde Hanefî mezhebinin önde gelen fakîhlerinden Serahsî (öl. 483/1090 [?]) “Sevilmeyen bir tasarruf olmakla beraber boşanma mubah olarak görülmüştür. Âlimlerin büyük çoğunluğu bu görüşü benimsemiştir." 25 söyleyerek âlimlerin çoğunluğunun bu görüşte olduğuna vurgu yapmıştır. Bu görüşü savunanlar, genelde boşanmanın helal veya sakıncalı olmayan bir tasarruf olduğunu ifade eden delilleri getirmişlerdir. $\mathrm{Bu}$ delillerin başında boşanmanın sakıncalı olmadığını gösteren "Kadınları boşamanızda sizin için bir sakınca bulunmamaktadır."26 meâlindeki âyet gelmektedir. $\mathrm{Bu}$ konuda en çok başvurulan diğer bir delil ise boşanmanın asıl itibariyle helal bir fiil olduğuna delalet eden "Allah katında en sevimsiz helal boşanmaktır." ${ }^{27}$ anlamındaki hadistir.

20 Ebû Dâvûd, es-Sünen, “Kitâbu'ț-țalâk”, 4 (2177).

21 et-Talâk, 65/1.

22 Muhammed b. İsmail el-Buhârî, Șahîhhu'l-Buhârî, thk. Muhammed Züheyr (b.y.: Dâru Tavki'n-Necât, 1422/2001) "Kitâbu'ț-țalâk", 43, (No. 5332).

23 Muhammed b. İbrahim İbn Münzir, el-i̇şrâf 'alâ mezhebi'l-'ulemâ, thk. Sağîr Ahmed (b.y.: Mektebetu Mekke es-Sikâfiyye, 1425/2004), 5/183.

24 Muhammed b. Ahmed el-Kurtubî, el-Câmi' li ahkâmi'l-Kur'an (Kahire: Dâru'lKütübi'l-Misriyye, 1384/1964), 3/126.

25 Muhammed b. Ahmed es-Serahsî, el-Mebsût (Beyrut: Dâru'l-Ma'rife, 1414/1993), 6/2.

26 el-Bakara, 2/236.

27 Ebû Dâvûd, es-Sünen, "Kitâbu't-țalâk", 4 (No. 2178). 
M. A. YAŞAR / The Judgment and Legal Consequence of Abuse of Divorce Authority in Islamic

Family Law | 99

b) Bir kısım fukahâya göre ise zaruri bir durum ortaya çıkmadı̆̆ 1 sürece boşanmada aslolan haramlıktır. İbn Teymiyye (öl. 728/1328) bu görüşü şöyle ifade etmiştir: "Zaruri bir durum olmadığı müddetçe boşanma haram olarak görülmelidir. İlgili delil ve usûller bunu iktiza etmektedir. Fakat zaruri hallerde boşanma insanlar için bir rahmet olarak sunulmuştur." ${ }^{28}$ Bu görüşün desteklenmesinde şu deliller öne çıkmaktadır: "Ĕğer size itaat ederlerse artık onlarm aleyhine başka bir yol aramayın." 29 ve "Allah, sırf zevk amacıyla çok evlenip boşanana lanet etmiştir." ${ }^{30}$ Vehbe Zuhaylî, hem şerî̀ maksatlarla uyuştuğu hem de boşanmadan kaynaklanan birçok tehlikenin önüne geçtiği için bu görüşün daha tercihe şayan olduğunu belirtmektedir. ${ }^{31}$

Boşanma yetkisinin asıl amacı dışında kullanılmasının hükmüne gelince; bu konuda fukahânın boşanma olgusunun asıl itibariyle mubah olup olmadığı hususundaki ihtilaflarına bağlı olarak iki farklı görüş ortaya çıkmıştır. Esasında klasik dönem fakîhleri doğrudan bu tür boşanmanın şer'î hükmüne değinmemişlerdir. Daha çok bunun ferî̂ meselelerinin hukukî sonuçlarıyla ilgilenmişlerdir. Bu yüzden burada konuyla ilgili fıkhî hüküm, fakîhlerin ilgili meselelere ilişkin düşüncelerinden ve onların "hak" nazariyeleriyle ilgili görüşlerinden hareketle tespit edilmeye çalışılacaktır. Buna göre boşanmanın aslî hükmünü mubah olarak gören görüşü esas aldığımızda bu türden boşanmanın hükmünü caiz olarak görmemiz gerekir. Çünkü bu görüşe göre boşama aslı itibariyle yasal bir hak olup onun sahibi -naslarla yasaklanan durumlar hariç- istediği zaman bu hakkı kullanma yetkisini haizdir. Nitekim mutlak hak nazariyesini ${ }^{32}$ savunan fakîhlere göre ister başkasına zarar versin ister vermesin hak sahibi hakkını kullanmakta serbesttir. Bu, hiçbir şekilde engellenemez..33 Ancak bu görüşe göre

28 İbn Teymiyye, el-Fetâve'l-kubrâ, 3/211.

29 en-Nisâ, 4/34.

30 Ali b. Muhammed el-Kârî, Mirkâtü̈l-mefâtih şerḥu Mişkâti'l-meșâbîh (Beyrut: Daru'lFikr, 1422/2002), 5/2137.

31 Vehbe b. Mustafa ez-Zuhaylî, el-Fıkhü'l-i̇slâmî ve edilletühu (Dımaşk: Dâru'l-Fikr, ts.), 9/6921.

32 Mutlak hak nazariyesi, hak sahibinin hiçbir surette hakkını kullanmaktan engellenememesi demektir. Aslan, “İslam Hukukunda 'Ta'assuf' Kavramı ve Hükümlere Etkisi", 216.

33 Serahsî, el-Mebsût, 15/21. 
100 | M. A. YAŞAR / İslâm Aile Hukukunda Boşanma Yetkisinin Kötüye Kullanılmasının Hükmü ve Hukukî Sonucu

boşanma meşru bir yetki olmakla beraber şer'î bir zorunluluk olmadığ1 sürece evlâ olan bunun kullanılmamasıdır. ${ }^{34}$ Yani bahse konu boşanma hilaf-i evlâ olarak değerlendirilir. Buna karşı boşanmada aslolan haramlık olduğunu düşünen fukahânın görüşünü temel aldığımızda ise söz konusu boşanmayı haram olarak kabul etmemiz lazım gelir. Nitekim bu görüşe göre ancak eşler arasında şiddetli geçimsizlik gibi zaruri bir durum ortaya çıktığında boşanmaya cevaz verilebilir; aksi halde boşanma olgusu aslî hükmü olan haramlık üzerine bırakılmalıdır. İbn 'Âbidîn (ö. 1252/1836) bunu şöyle izah etmiştir:

"Boşanmada aslolan haramlıktır. Yani caiz kılacak bir durum ortaya çıkmadıkça boşanmanın haram olarak görülmesi gerekir. Zaten fakîhlerin ‘Boşanmanın aslî hükmü haram olmakla beraber (şiddetli anlaşmazlık yüzünden sürdürülmesi imkânsız hale gelen evlilik birlikteliğinden kurtulmak amacıyla) bir çözüm yolu olarak boşanmaya cevaz verilmiştir.' şeklindeki ifadeleri bundan ibarettir. Hâl böyle olunca boşanmayı gerektiren herhangi bir sebep meydana çıkmadığı sürece bu yola tevessül edilmemeli; aksi takdirde bunu yapmak ahmaklık, aptallık ve cahillik olup aile ve çocuklara zarar vermekten başka bir şeye yaramaz."

İbn 'Âbidîn devamında şunları kaydetmiştir: "Boşanmayı gerektiren şer'î bir gerekçe bulunmadiğı sürece boşanma olgusu aslî hükmü olan haramlık üzerine kabul edilmelidir." 35

Zikredilen görüşlerden boşanmada aslolan haramlık olduğu yönündeki görüşün tercih edilmesi daha isabetli görünmektedir. Zira evlilik, süreklilik isteyen, dinî ve dünyevî birçok maslahatı şâri'in maksadına uygun bir biçimde gerçekleştiren bir akittir. Zorunlu bir durum olmadıkça bu akdin sonlandırılmasına, dolayısıyla da sözü edilen maslahatların kaçırılmasına izin verilmemelidir. ${ }^{36}$ Karşıt görüştekilerin delillerinden "boşanmanın sakıncalı bir tasarruf olmadığııı" gösteren âyetin hükmü genel değildir. Henüz dokunmayan veya mihri belirlenmeyen kadınların boşanmasıyla münhasırdır. Dolayısıyla bu âyet, boşanmanın aslî hükmünün mubah olduğunu göstermez. ${ }^{38}$ Yine

34 Şîrîn Zuheyr Ebû 'Abdû, Ma'âlimü'l-üsreti'l-muslime fi'l-Kur'ani'l-Kerîm (Gazze: elCâmi’atü'l-İslâmiyye, Yüksek Lisans Tezi, 1430/2010), 103.

35 İbn 'Âbidîn, Reddü'l-muhtâr, 3/228.

36 Hallâf, Aḥkâmü'l-aḥvâli'ş-şahșiyye, 146.

37 el-Bakara, 2/236.

38 Muhammed Ebû Zehra, el-Ahvâlü'ş-şahsiyye (Kahire: Dâru'l-Fikri'l-'Arabî, ts.), 284. 
M. A. YAŞAR / The Judgment and Legal Consequence of Abuse of Divorce Authority in Islamic

Family Law | 101

"boşanmayı sevimsiz bir helal"39 olarak gösteren hadisin hükmü da boşanmanın zaruri bir hal aldığı durumlar ile takyîd edilmiştir. İbn 'Âbidîn İbnü'l-Hümâm'dan (öl. 861/1457) naklen "(Hadiste geçen mubah ifadesi) boşanmanın helal kılındığ1 vakitlere hamledilmektedir." diyerek buna vurgu yapmıştır. ${ }^{40}$ Buna binaen bahse konu boşanma türünün haram olarak görülmesinde bir sakıncanın olmaması gerekir. Nitekim aslı itibariyle boşanmayı mubah görenlerin aksine meşru hakların kullanılmasında aslolan mutlak serbestlik değildir. Bilakis Fethî ed-Dirînî'nin de ifade ettiği gibi meşru hakkın kullanım yetkisi şer'in maksadına aykırı düşmemesi ve başkasına zarar vermemesiyle kayıtlanmıştır. ${ }^{41} \mathrm{Bu}$ sebeple zaruri ihtiyaç sonucunda bir çözüm yolu olarak şâri' tarafında sunulan boşanma hakkı, bu amaç dışında kullanılırsa şer' in maksadına terse düşmüş olur. Bu ise şer'an sabit olan bir hakkın meşru olan amacı dışında kullanılması olur ki buna cevaz verilmemiştir. Bunun yanı sıra bu türden boşanmadan genellikle karşı tarafın zarara uğratılması amaçlanmaktadır. Sebepsiz yere başkasına zarar vermek ise kesin delillerle haram kılınmıştır. Bu delillerin başında Resûlüllah'tan (s.a.v.) rivayet edilen "Zarar ve zarara zararla karşılık vermek yoktur." 42 anlamındaki hadistir. Aynı zamanda genel bir fikhî kaide olarak da fukahâ tarafından çokça müracaat edilen hadisin hükmü, âmm olup kimden ve ne şekilde geldiğine bakılmaksızın, haksız yere yapılan zararın her türlüsünün haram olduğunu göstermektedir. Aynı şekilde kadının kocasına zarar vermek amacıyla tefvîz yöntemiyle evlilik akdini bitirmesi, bir kısım fukahâ tarafından mekruh olarak görülse de ${ }^{43}$-boşanmada olduğu gibi- haram olarak kabul edilmesi daha isabetli görünmektedir. ${ }^{44}$ Nitekim sonuç itibariyle nikâh akdini bitiren bir anlaşma olması hasebiyle bahsi geçen yöntem -birçok fakîhin

39 Ebû Dâvûd, "Kitâbu'ț-țalâk"̣", 4, (No. 2178).

40 İbn 'Âbidîn, Reddü'l-muhtâr, 3/228.

41 Dirînî, Nazariyyetü't-ta'assuff, 34.

42 İbn Mâce, es-Sünen, "Kitâbu'l-ahkâm”, 17, (No. 2341).

43 İbn Kudâme, el-Mug்nî, 7/323; Komisyon, el-Mevsû'atü'l-fikhiyye (Kuveyt: Dâru'sSelâsil, 1427/2006), 19/240.

44 Mâlikîler hul' ile yapılan bu tür boşanmayı haram görmüşlerdir. Muhammed $b$. Ahmed b. Rüşd el-Cedd, el-Mukaddimâtü'l-mümehhidât, thk. Muhammed Hacî (Beyrut: Dâru'l-Garbi'l-İslâmî, 1408/1988), 1/559. 
102 | M. A. YAŞAR / İslâm Aile Hukukunda Boşanma Yetkisinin Kötüye Kullanılmasının Hükmü ve Hukukî Sonucu

belirtiği gibi-45 bir çeşit boşanma sayılması; dolayısıyla da yukarıda boşanma konusunda beyan ettiğimiz gerekçelere binaen haklı bir neden olmadan kadının bunu kötüye kullanmasının caiz görülmemesi hakkaniyete daha uygun olacaktır. Zaten "Geçerli bir neden olmaksızın kocasından boşanmasını isteyen kadına cennetin kokusu haramdır." ${ }^{46}$ manasındaki hadis de bunu teyit etmektedir. Zira hadiste, dolaylı olarak azap ile tehdit söz konusudur. ${ }^{47}$ Tehdit ise ancak yapılması vâcib bir ibadetin terk edilmesinden veya haram bir şeyin işlenmesinden ötürü yapılır. ${ }^{48}$ Yine hadis ve sahâbe uygulamalarında anlatılan bu tür anlaşmalarının hemen hepsinin karı ile koca arasında yaşanan geçimsizlikler yüzünden yapılmış olması böyle anlaşmalar ancak zorunlu durumlarda başvurulduğunu göstermektedir. ${ }^{49}$

\section{Boşanma Yetkisinin Kötüye Kullanılmasının Hukukî Sonucu}

Hiçbir şer'î gerekçe olmadan sırf karşı tarafa zarar vermek için yapılan boşamanın hükmünün haram olarak görülmesinin daha isabetli olacağına yukarıda temas ettik. Söz konusu boşanmanın geçerli olup olmayacağ1 hususuna gelince; bu konuda genel kanaat, haram bir tasarruf olarak görülmekle beraber böyle bir boşanmanın geçerli olacağı, dolayısıyla da ilgili fikhî hükümlerin kendisine terettüp edeceği yönündedir. Nitekim klasik fıkıh kaynaklarına baktığımızda genelde bu tür boşanmanın hukukî sonuçlarından söz ettiklerine şahit oluyoruz. Bunu geçersiz gören kimseye rastlamadık. Çağdaş hukukçulardan Fârûk Abdullah bu konuda şunları kaydetmektedir:

“Fukahânın çoğunluğuna göre boşanma hakkı onu gerekli kılan durumlarla sınırlıdır.

Zorunlu bir durum olmadan boşanmayı gerçekleştiren kişi günahkâr olur. Bu tarz

45 Nevevî, Ravdatü't-țâlibîn, 7/374; Osman b. Ali ez-Zeylaî, Tebyînül-hekâik şerḥu Kenzi'd-dekâik (Kahire: el-Matb'atu'l-Emîriyye el-Kübrâ, 1313/1896), 2/268.

46 İbn Mâce, "Kitâbu'țtṭalâk", 21, (No. 2055).

47 Muhammed b. Ali eş-Şevkânî, Neylü'l-evțâr, thk. İsâmüddîn es-Sabâbitî (Mısır: Dâru'l-Hadîs, 1413/1993), 6/262.

48 Muhammed b. Ömer er-Râzî, Mefâtihu'l-ġayb (et-Tefsîru'l-kebîr) (Beyrut: İhyâü'tTürâsi'l-'Arabî, 1420/1999), 6/531.

49 Ali b. Muhammed el-Mâverdî, el-Hâtvi'l-kebîr fi fiḳhi'l-imam eş-Şâfî̀ (Beyrut: Dâru'lKütübi'l-'İlmiyye, 1409/1999), 10/4-5; İbn Kudâme, el-Mug்nî, 7/323-324 
M. A. YAŞAR / The Judgment and Legal Consequence of Abuse of Divorce Authority in Islamic Family Law | 103 boşanmanın geçerliliği konusunda ise fukahâdan aykırı görüş beyan eden kimseye rastlamadım." 50

Hukukî sonuçları olan bu türden boşanmalar aşağıda verilmiştir.

\section{1. Ölüm Hastası Kocanın Hanımını Boşamasının Hukukî Sonucu}

F1kıh kaynaklarında "maraz-1 mevt/ölüm hastalığ1 veya maraz-i mahûf/korkulan hastalık" ifadeleriyle yer alan bu hastalık durumu fakîhler tarafından farklı şekillerde izah edilmiştir. ${ }^{51}$ Burada Mecelle- $i$ Ahkâm-ı Adliyye' de yer alan şu izahatı esas alacağız:

“Maraz-ı mevt, erkekleri ev dışındaki, kadınları ise ev içindeki işlerini göremez hale getiren ve genellikle üzerinden bir sene geçmeden ölümle sonuçlanan hastalıktır." 52

Mecelle'ye göre şu durumlar da ölüm hasatlığı hükmünde addedilmiştir: a) Kısas edilmek üzere katilin idam sahasına çıkarılması. b) Savaşçıların mübâreze meydanında birebir eşleşerek ölümüne vuruşmaları. c) Batan gemiden sağ kurtulan kişinin bir tahta parçasına tutunması. d) Kişinin yırtıcı hayvan pençesine düşmesi. ${ }^{53}$ Mecelle'nin açıklamasından anlaşıldığı üzere söz konusu hastalığın belirlenmesinde genelde şu kriterler esas alınmaktadır:

- Hastalığın çoğunlukla ölümle neticelenen hastalıklar cinsinden olması veya genellikle ölüme götüren tehlikeli bir durumun bulunması.

- Hastalığa yakalanan kişinin günlük işlerini tek başına yapamaz duruma düşmesi.

- Hastalığın tespit edilmesiyle birlikte hastanın iş yapamaz durumunun kesinlik kazanması ve yaşamasının bir seneyi aşmaması. ${ }^{54}$

Buna göre ölüm hastalığına düşen kişinin bir seneden az bir sürede ölmesi durumunda bu süre içinde yaptığı bütün tasarrufları

50 Fârûk Abdullah Kerîm, el-Vesît fî şerhi kânûni'l-ahvâli'ş-şahșiyye el-Irâk̂̉ (Süleymaniye: Câmi'atü's-Süleymaniyye, 2004), 177.

51 Bk. İbn Kudâme, el-Mug̉nî, 6/203; Abdulkerîm Zeydân, el-Mufașal fì aḥâmi'l-mer'e ve'l-beyti'l-müslim fi'ş-şerî'ati'l-İslâmiyye (Beyrut: Müessesetü'r-Risâle, 1413/1993), 10/361-365.

52 Ali Haydar Efendi, Dürerü'l-ḥükkâm şerḥu Mecelleti'l-ahkâm (b.y.: Dâru'l-Cîl, 1411/1991), 4/136.

53 Haydar Efendi, Dürerü'l-h̆̈̈kkâm, 4/136-137

54 Haydar Efendi, Dürerü'l-ḥükkâm, 4/137-138; Ali Bakkal, "Maraz-1 mevt”, Türkiye Diyanet Vakfı İslâm Ansiklopedisi (Ankara: TDV Yayınları, 2003), 28/39. 
104 | M. A. YAŞAR / İslâm Aile Hukukunda Boşanma Yetkisinin Kötüye Kullanılmasının Hükmü ve Hukukî Sonucu

ölüm hastalığı hükmüne tabi tutulur. Buna karşı kişinin bir seneden fazla yaşaması veya ölümcül hastalıktan iyileşmesi ya da ölümcül tehlikeden kurtulması halinde ise hastalık veya ölümcül tehlike süresi içinde gerçekleştirdiği işlemlerinin tümü, sağlıklı halinde yapılan tasarruflar cinsinden sayılır ve geçerli olarak kabul edilir. ${ }^{55}$

Bilinci yerinde olduğu sürece ölüm hastalı̆̆ı, kişinin vücûb ehliyetine ${ }^{56}$ engel değildir. Çünkü bu hastalık kişinin düşünmesine ve konuşmasına engel teşkil etmemektedir. Aynı şekilde akla herhangi bir halel getirmeyeceği gerekçesiyle kişinin edâ ehliyetine ${ }^{57}$ de mani değildir. Hâl böyle olunca bu hastalığa düşen kişi hak ve borçlar altına girebildiği gibi onun alışveriş gibi ivazlı/karşılıklı tasarrufları da geçerli olur. ${ }^{58}$ Ancak ölüm hastalığında veya bunun hükümde olanların, içinde bulunduğu durumun etkisiyle özellikle alacaklı ve vârislerin haklarını ihlâl edecek bazı işlemler yapabileceği düşüncesiyle ivazsız olan bazı tasarruflarının kısıtlanmasına gidilmiştir. Buna göre ölüm hastası kişinin alışveriş ve icâre gibi ivazlı sözleşmeleri -alıcıyı kayırdığına dair kanıt bulunmadığı sürece- geçerlidir. Hastanın ölümünden sonra ne alacaklı ne de varisler buna karşı çıkabilir. Çünkü bu gibi tasarruflar, karşılıklı olduğundan hastanın mülkünden bir şeyi eksiltmez. Dolaysıyla da alacaklı ve varisler herhangi bir hak iddia edemezler. Aynı şekilde sözü edilen hastanın, varisleri dışında birisinin lehine borç ikrarında bulunmasında da bir mani bulunmamaktadır. Buna mukabil ölüm hastasının hibe ve vakıf gibi teberru/karşılıksız tasarrufları ve alıcıya iltimas geçtiği belirgin olan alışverişleri ise alacaklı ve varislere zarar verdiği gerekçesiyle, vasiyete olduğu gibi malının üçte biriyle sınırlı tutulur. Malının üçte birini aşan kısımda tasarrufları durdurulur ve ancak varislerinin onayı ile geçerlilik kazanır..$^{59}$

55 İbn Kudâme, el-Muginni, 6/202; Muhammed b. Ahmed er-Remlî, Nihâyetü'l-muhtâc ilâ şerhi'l-Minhâc (Beyrut: Dâru'l-Fikr, 1404/1984), 6/59.

56 Kişinin dinî ve hukukî haklara sahip olabilme ve borç altına girebilme yeteneğidir. Ali Bardakoğlu, "Ehliyet", Türkiye Diyanet Vakfı İslâm Ansiklopedisi (Ankara: TDV Yayınları, 1994), 10/534.

57 Kişinin sahip olduğu hakları bizzat kullanabilme ve bizzat kendi işlemiyle borç altına girebilme ehliyetidir. Bardakoğlu, "Ehliyet", 10/535-536.

58 Zuhaylî, el-Fıkhü'l-İslâmî, 4/2978-2979.

59 İbn Kudâme, el-Muğnî, 5/157, 237; 6/193; Şirbînî, Mug்ni'l-muḥtâç, 3/523. 
M. A. YAŞAR / The Judgment and Legal Consequence of Abuse of Divorce Authority in Islamic

Family Law | 105

Ölüm hastasının evlenmesinin geçerli olup olmayacağı meselesi fakîhler arasında tartışma konusu olmuştur. Buna göre Mâlikî fakîhleri, erkek veya kadının yabancı birisini mirasçı veya mehir alacaklısı yapmak suretiyle varislere zarar vermek istediği kuşkusu bulunduğu için bu durumdaki nikâhın fasid olduğuna hükmetmişlerdir. ${ }^{60}$ Cumhur ise evlenmenin de hevâic-i asliyeden olduğunu, dolayısıyla da buna herhangi bir mâninin olmaması gerektiğini ifade ederek böyle bir hastalık esnasında mehr-i misil ile yapılan nikâhı sahih görmüşlerdir. Onlara göre mehr-i misli aşan kısım geçersizdir. ${ }^{61}$ Yine sözünü ettiğimiz hastanın boşamasının geçerli olduğu hususunda ittifak vardır. ${ }^{62}$ Ancak bu gibi durumlarda kocanın eşini mirastan mahrum etme kastı hayli yüksek bir ihtimal olduğundan fakîhler, bu boşanmayı geçerli görmesine rağmen boşanan kadının mirasçı olup olmayacağ 1 konusunda ihtilafa düşmüşlerdir.

Literatürde söz konusu boşanma için "طلاق الفار/(mirası) kaçıranın boşaması" tabiri de kullanılmaktadir. ${ }^{63} \mathrm{Bu}$ durumda bulunan koca eşini ric'i talâk ile boşar ve iddet süresi içinde vefat ederse kadın -rızası olsun veya olmasın- mirasçı olur. Çünkü bu durumda hükmen de olsa evlilik bağ 1 devam etmektedir. Bu konuda fakîhler hemfikirdirler. ${ }^{64}$ Yine fukahâ, bâin talâkla boşanmayı gerçekleştiren ölüm hastası kocadan önce karısının vefat etmesi halinde kocanın mirasçı olamayacağı hususunda da ittifak etmişlerdir. Zira bu durumda kocanın kendi rızasıyla mirastan vazgeçtiğine hükmedilmektedir. ${ }^{65}$

Ölüm hastası koca eşini bâin talâk ile boşar ve iddet müddeti içerisinde vefat ederse kadının mirasçı olup olmayacağı tartışılmıştır. Hanefî ve Mâlikî mezheplerine, Hanbelî mezhebinin sahîh görüşüne ve Şâfiî’nin kadim görüşüne göre bu durumda kadın şu şartlarla mirasçı olur: a) Zifafın gerçekleşmiş olması gerekir. Bundan dolayı boşanma

60 Muhammed b. Ahmed es-Sâvî, Hậşiyetü'ṣ-Ṣ̂â̂ 'ala'ş-Şerhị'ṣ-Ṣağîr (b.y.: Mektebetu Mustafa'l-Bâbi'l-Halebî, 1372/1952), 2/145.

61 Muhammed b. Hasen eş-Şeybânî, el-Hucce 'alâ ehli'l-Medîne (Beyrut: 'Âlemü'l-Kütüb, 1403/1983), 3/495; Mâverdî, el-Hâvi'l-kebîr, 8/279.

62 Şirbînî, Muğni'l-muhtâç, 4/477; İbn 'Âbidîn, Reddü'l-muhtâr, 3/383.

63 Bâbertî, el-'ínâye, 4/145.

64 Bâbertî, el-'Inâye, 4/145; Komisyon, el-Mevsû'atü'l-fikhiyye, 29/49.

65 Zuhaylî, el-Flkhü̈l-İslâmî, 9/6978. 
106 | M. A. YAŞAR / İslâm Aile Hukukunda Boşanma Yetkisinin Kötüye Kullanılmasının Hükmü ve Hukukî Sonucu

zifaf olmadan gerçekleşmişse kadın mirasçı olamaz. b) Boşanma kadının rızası dışında yapılmış olmalıdır. Aksi takdirde kadın miras hak iddia edemez. c) Boşanma sırasında karı ve kocanın birbirlerine mirasçı olabilme pozisyonunda olmaları şarttır. Buna göre boşanma esnasında kitabî olan kadın iddet süresi içerisinde ve kocanın vefatından önce Müslüman olsa bile mirasçı olamaz. Bu görüşün desteklenmesi için nakli ve aklî olmak üzere iki farklı delil serdedilmiştir. Nakli delil olarak sahâbenin, sözünü ettiğimiz görüşü destekler nitelikte birçok uygulamalari $^{66}$ bulunmasına rağmen genellikle Hz. Osman'ın Abdurrahman b. 'Avf'ın (öl. 32/652) ölüm döşeğindeyken eşini Tümâdir'1 bâin talâkla boşadığı halde Tümâdir'ı ona mirasçı kılması ${ }^{67}$ şeklindeki olay gösterilmektedir. Hz. Osman'ın Müslümanların halifesi sıfatıyla sahâbîlerin huzurunda verdiği bu fetvaya, kimse karşı çıkmadığı için icmâ olarak kabul edilmiştir. ${ }^{68}$ Aklî delil ise şöyledir: Ölüm hastalığı halinde gerçekleşen boşanma, genellikle kadını mirastan mahrum etmeye yönelik olduğu açıktır. Hâl böyleyken malına konmak amacıyla mûrisini öldüren mirasçının, amacına aykırı olarak mirastan mahrum bırakılması gibi kötü niyetli kocanın maksadına aykırı olarak kadının mirasçı kılınması hakkaniyete daha uygun düşecektir. ${ }^{69}$ İbn Ebî Zeyd (öl. 310/922) bunu şöyle anlatmıştır:

“Resûlüllah (s.a.v.) mûrisini öldüren mirasçıyı, öldürmekten dolayı mirastan mahrum ettiğine göre ölüm hastası koca tarafından boşanan kadının da mirastan mahrum edilmemesi gerekir. Zikredilen her iki mirasçı arasında fark bulunmamaktadır. Zira bunlardan biri mirası almak için bir sebebe başvurmuş; ancak aynı sebep yüzünden

66 Bk. Yusuf b. Abdullah b. Muhammed el-Kurtubî, el-İstizkâr, thk. Sâlim Muhammed 'Atâ-Muhammed Ali Mu'avviz (Beyrut: Dâru'l-Kütübi'l-'Illmiyye, 1421/2000), 6/112113.

67 Ahmed b. Muhammed b. Hanbel eş-Şeybânî, el-Müsned, thk. Şuayb el-Arnavutî vd. (b.y.: Müssesetü'r-Risâle, 1421/2001), 11/464, (No. 6877).

68 Muhammed b. Abdillâh el-İşbîlî, el-Mesâlik fî şerhịi Muvațtá Mâlik (b.y.: Dâru'lGarbi'l-İslâmî, 1428/2007), 5/606.

69 Abdulmelik b. Abdillah el-Cüveynî, Nihâyetü'l-mațeb fî dirâyetü'l-mezheb, thk. Abdulazîm Mahmud ed-Dîb (b.y.: Dâru'l-Minhâc, 1428/2007), 14/231; Âlâüddîn b. Mes'ud el-Kâsânî, Bedâi'u'ș-șanâi' fì tertibi'ş-şerâi' (b.y.: Dâru'l-Kütübi'l-'Illmiyye, 1406/1986), 3/218; Abdurrahman b. Muhammed İbn Kudâme, eş-Şerḥu'l-kebîr 'alâ metni'l-Mukni' (b.y.: Dâru'l-Kitâbi'l-'Arabî, ts.), 7/181; Mansûr b. Yunus el-Buhûtî, Keşşâfül-kinina' 'an metni'l-ịknâ' (b.y.: Dâru'l-Kütübi'l-'İlmiyye, ts.), 4/481. 
M. A. YAŞAR / The Judgment and Legal Consequence of Abuse of Divorce Authority in Islamic

Family Law | 107

mirastan mahrum bırakılmıştır. Diğeri ise kişi mirastan mahrum bırakılmak için bir yola müracaat edilmiş; ancak o kişi aynı yol sebebiyle mirasçı kılınmıştır. Hâl böyleyken ölüm hastalığı içerisinde mirastan mahrum bırakılmak amacıyla boşanan kadının mirasçı kılınması gerekir..."70

Yani her iki olayda da hedeflenen kötü niyetin tersine bir hükmün verilmesi öngörülmüştür. İmam Şâfiî̀'nin cedîd görüşüne göre bahse konu boşanmada kadın mirasçı olamaz. İmam Şâfiî’nin bu görüşü şöyle gerekçelendirilmiştir: Karı ile koca arasındaki mirasçılık ilişkisi olan evlilik bağı bâin talâkla son bulduğundan boşamayı yapan hasta kocanın, kendisinden önce vefat eden karısına mirasçı olamayacağı gibi bunun aksi de mümkün değildir. Ayrıca İbnü'z-Zübeyr (öl. 73/692), Hz. Osman'ın bâin talâkla boşanan Abdurrahman b. 'Avf'un eşini ona mirasçı kılmasını doğru bulmayarak karşı çıkmıştır ki bu da karşıt görüştekilerin ifade ettiğinin aksine konuya ilişkin icmânın oluşmadığını göstermektedir. ${ }^{71}$

Ölüm hastası kocanın eşini boşaması ve iddet bittikten sonra vefat etmesi halinde boşanan kadının kendisine mirasçı olup olamayacağ konusunda da ihtilaf vardır. Hanefî ve Şâfiî mezheplerine göre bu durumda kadın mirasçı olamaz. Çünkü eşler arasındaki mirasçılık sebebi olan evlilik bağı iddetin bitmesiyle son bulmaktadır. ${ }^{72}$ Ahmed b. Hanbel'in meşhur görüşüne göre iddeti sona erse de sözü edilen kadın, başka birisiyle evlenmediği sürece mirasçı kılınır. Zira kocanın ölüm hastalığ 1 içerisinde böyle bir tasarrufta bulunması, amacının kadını mirastan mahrum etmek olduğunun göstergesidir. Bu yüzden kocanın kötü niyetine karşılık olarak kadının mirasçı kılınması daha isabetli olacaktır. Kadının başka birisiyle evlenmesi durumunda ise bir kadının aynı anda iki koca ile evli bulunması şer'î açıdan mümkün olmadığı için iki ayrı kocaya mirasçı olması da söz konusu olmamalıdır. Nitekim eşler arasındaki mirasçılık, nikâh sonucu kazanılan bir hak olduğu için mevcut nikâh ile başka bir nikâhın birleşmesi caiz değildir. Ayrıca başka birisiyle evlenmesi kadının kendi rızasıyla ilk evliliğiyle çelişen bir

70 Abdurrahman b. Mervân el-Kanâzi'î, Tefsîru'l-Muvatța', thk. 'Âmir Hüseyin Sabrî (Katar: Dâru'n-Nevâdir, 1429/2008), 1/376.

71 Mâverdî, el-Hâvi'l-kebîr, 10/265; Şirbînî, Mugini'l-muhtâç, 4/477.

72 Muhammed b. Hasan eş-Şeybânî, el-Așl, thk. Muhammed Boynukalın (Beyrut: Dâru İbn Hazm, 1433/2012), 4/528-529; Şâfî̂, el-Ümm, 5/271. 
108 | M. A. YAŞAR / İslâm Aile Hukukunda Boşanma Yetkisinin Kötüye Kullanılmasının Hükmü ve Hukukî Sonucu

eylemde bulunması anlamındadır. Bu ise boşanmanın kadının rızasıyla gerçekleştiğine benzer ki bu durumda kadın mirasçı kılınamaz. ${ }^{73}$ Mâlikî mezhebine göre iddeti bitse ve başka birisiyle evlense bile kadının mirasçı kılınması esastır. Çünkü bu konuda kadının mirasçı kılınmasından temel gaye, kötü niyetine karşılık olarak kocanın cezalandırılmasıdır. Bu gayenin ise iddetten sonra devam etmesi gerektiği gibi kadının başka birisiyle evlenmesiyle de son bulmaması gerekir. ${ }^{74}$

Ölüm hastalığı esnasında gerçekleşen boşanmada, kocanın vefatı ister iddet süresi içeresinde veya sonrasında olsun ve kadın ister başka birisiyle evlenmiş olsun veya olmasın, boşanma eylemi rızası dışında olduğu sürece kadını mirasçı kılan Mâlikî mezhebinin görüşü daha isabetli görünmektedir. ${ }^{75}$ Nitekim bu tür durumlarda kadının mirasçı kılınması, herhangi bir şer'î gerekçe olmadan -meşru bir hak olan boşanma yetkisi alet edilerek- kadının hakkının gasp edilmesine karşı alınan en önemli tedbirdir. ${ }^{76}$ Zira şer'î açıdan tanınan bir hakkın engellenmesi, şahsî menfaatler doğrultusunda değil, meşru görünen gerekçelerle olmalıdır. Kadının mirasçılığı ise şer^̂̂ olarak kocanın hastalığıla sabit olan bir hak olduğuna göre kocanın keyfî davranışlarına kurban edilmemelidir. ${ }^{77}$ Zaten mirasçların haklarının korunması kastıyla ölüm hastasının teberru olan tasarruflarının üçte birlik kısımla sınırlandırılması bunun açık kanıtıdır. Çünkü meşru mirasçılar arasında yer alan kadının da hakkının elinden alınmaması için her türlü tedbirin alınması gereklidir. Mirasçılık hakkını, Şâfiî’'de olduğu gibi evlilik ilişkisine bağlayıp bu ilişkinin bâin talâkla veya Hanefîler'in savunduğu üzere iddetin bitmesiyle ya da Hanbelî́nin meşhur görüşünde olduğu şekilde kadının başka biriyle evlenmesiyle son bulduğunu iddia edenlere şu şekilde cevap verilebilir: Evlilik ilişkisi

73 İbn Kudâme, eş-Şerhu'l-kebîr, 7/182; Zuhaylî, el-Fıḷhü'l-İslâmî, 9/6979.

74 Mâlik b. Enes, el-Müdevvene (b.y.: Dâru'l-Kütübi'l-'Ilmiyye, 1415/1994), 2/86-87; Adem Çiftci, "Vaktinden Önce Yapılan Tasarrufların Fıkhî Hükümlere Etkisi (Aile Hukuku Özelinde)", İslam Hukuku Araştırmaları Dergisi 33 (2019), 381.

75 Süleymân b. Halef b. Sa'd el-Bâcî, el-Müntekā (Mısır: Matba'atü's-Sa'âde, 1332/1914), $4 / 85$.

76 Zeydân, el-Mufașsal, 10/377.

77 Ali b. Halef İbn Battâl, Şerḥu Șahîhhi'l-Buhârrî, thk. Ebû Temîm Yâsir b. İbrahim (Riyad: Mektebetü'r-Rüşd, 1423/2003), 7/395. 
M. A. YAŞAR / The Judgment and Legal Consequence of Abuse of Divorce Authority in Islamic

Family Law I 109

sıralanan nedenlerle son bulsa da miras hakk1 bunlarla son bulmamaktadır. Çünkü İbn Battâl'ın (öl. 449/1057) ifade ettiği üzere kadının miras hakkı kocanın ölüm hastalığına yakalanmasıyla sabit olur. İbn Teymiyye de bunu açık bir şekilde ifade etmiştir. ${ }^{78}$ Ölüm hastalığının başlanmasıyla birlikte kişinin tasarruf yetkisi kısıtlanarak diğer mirasçıların hakları korunduğu gibi kadının miras hakkı da evlilik bağının kopmasıyla elinden alınmamalıdır. Ayrıca bu konuda kadının mirasçı kılınmasından asıl amaç, ölüm hastası kocanın kötü emelinin tersine bir hüküm verip bunun önüne geçmek olduğundan evlilik ilişkisinin bitmesi, buna engel teşkil etmemelidir. Yine sahâbenin konuya ilişkin uygulamalarının genelinin kadının mirasçı kılınması yönünde olması da daha isabetli gördüğümüz görüşü destekler mahiyetedir.79 Hatta Ebü'l-Velîd el-Bâcî (öl. 474/1081) bu konuda sahâbenin icmâı bulunduğunu, bu görüş Hz. Ömer ve Hz. Osman ve diğer sahâbîlerden rivâyet edildiğini ve İbnü'z-Zübeyr dışında kimse buna karşı çıkmadığını söyleyerek söz konusu durumda boşanan kadının, hiçbir sınırlama olmaksızın mirasçı kılınması daha doğru olacağına vurgu yapmıştır. ${ }^{80}$ İbnü'z-Zübeyr'in sahâbenin geneline muhalif olarak "bâin talâkla boşanan kadının mirasçı kılınamayacağı" şeklinde verdiği muhalif fetvası ise şöyle yorumlanmıştır: Onun bu fetvasını, sahâbenin konuya ilişkin içtihatlarından haberdar olmadığ zamanda vermiş olma ihtimali bulunduğu gibi bunu sahâbenin icmâından sonra vermiş olması da muhtemeldir. ${ }^{81}$

\section{2. Ölüm Hastası Kadının Hul` Yöntemiyle Kocasından} Ayrılmasının Hukukî Sonucu

"Hul" sözlükte çıkarmak, ayırmak, izale etmek gibi manalarda kullanılmaktadır. ${ }^{82}$ Istılahî anlamda ise mezheplerin konuya

78 İbn Battâl, Şerḥu Ṣahîhịi'l-Buhââi, 7/395; İbn Teymiyye, el-Fetâve'l-kubrâ, 3/321.

79 Nitekim Hz. Osman'ın iddet öncesi veya sonrası diye bir zaman belirtmeden Abdurrahman'a "ölürsen Tümâdir'ı sana varis kılacağım” şeklinde mutlak bir ifade kullanması buna işaret etmektedir. İbn Kudâme, el-Mug்nî, 6/395.

80 Bâcî, el-Müntekāa, 4/85.

81 İbn Kudâme, el-Muğnî, 6/395.

82 İbn Manzûr, Lisânü'l-'Arab, “hull”, 8/76. 
110 I M. A. YAŞAR / İslâm Aile Hukukunda Boşanma Yetkisinin Kötüye Kullanılmasının Hükmü ve Hukukî Sonucu

yaklaşımlarına bağlı olarak hul'un, farklı tanımları yapılmıştır. ${ }^{83} \mathrm{Bu}$ farklı tanımlardan hareketle şöyle bir tanım yapılabilir: Hul' veya bu manaya gelen bir ifade ya da talâk kelimesi kullanmak suretiyle kocanın, kadın tarafından ödenen belli bir bedel karşılığında evlilik akdini sonlandırmasıdır. Hul', evlilik görevlerinin yerine getirilemeyeceğinden endişelendiği, karşılıklı anlaşmazlık yüzünden evlilik birlikteliğinin sürdürülmesi zor bir hal aldığı ve evlilikten beklenen hedeflerin gerçekleşmesinin mümkün görülmediği durumlarda başvurulan bir çözüm olarak meşru kılınmıştır. ${ }^{84}$

Hul'un mahiyet itibariyle talâk $\mathrm{m} 1$ veya fesih mi ve buna bağlı olarak da bunlardan hangisinin hükmüne tabi tutulacağ ${ }_{1}$ hakkında ihtilaf olmakla beraber, böyle bir anlaşmayla evlilik akdinin sonlandırılmasının mümkün olduğu hususunda ittifak vardır. ${ }^{85}$ Geçerli bir neden olsun veya olmasın, ilgili şartlar çerçevesinde gerçekleştirilen hul' anlaşması geçerli kabul edilir. Bu konuda karı veya kocanın sağlıklı veya ölüm hastası olması hükmü değiştirmez. Bunda ihtilaf söz konusu değildir. ${ }^{86}$

Ölüm hastası kadın hul' anlaşmasını gerçekleşir ve bu hastalık sonucunda ölürse kocanın miras payından veya hul' bedelinden hangisini hak edeceği hususunda ihtilaf edilmiştir. Buna göre Hanefî mezhebine göre ölüm hastası kadın, kocasının verdiği mehr-i misil üzerine hul' yapar ve iddeti bitmeden ölürse bu durumda kadının mehri misil dışında malı varsa koca, kendi payına düşen mirastan ve belirlenen mehirden; mehir dışında malı olmadığı durumda ise mirastan ve mehrin üçte birden en az olanı alır. Kadın iddetten sonra vefat ederse

83 Nevevî, Ravdatü't-tâlibîn, 7/374; Bâbertî, el-'Inâye, 4/211; Muhammed b. Ahmed b. Muhammed 'Alîş, Menḥu'l-celîl şerḥu Muhtașari'l-Ḩalîl (Beyrut: Dâru'l-Fikr, 1408/1989), 4/3.

84 Kurtubî, el-Câmi', 3/138; Şirbînî, Muğni'l-muhtâç, 4/436; Zuhaylî, el-Fıkhü̈l-İslâmî, 9/7009.

85 Abdullah b. Ahmed İbn Kudâme, el-Kâfí fî fikhi'l-imâm Ahmed (b.y.: Dâru'l-Kütübi'l'İlmiyye, 1414/1994), 3/98; Serahsî, el-Mebsûtt, 6/171; Muhammed b. Muhammed Hattâb er-Ru'înî, Mevâhibü'l-celîl fì şerhịi Muhtașari Hualîl (b.y.: Dâru'l-Fikr, 1412/1992), 4/19; Şirbînî, Muggni'l-muhtâç, 4/430.

86 Şâfiî, el-Ümm, 5/214; İbn Kudâme, el-Muginnt, 7/355-356; Zeydân, el-Mufașsal, 10/377378. 
M. A. YAŞAR / The Judgment and Legal Consequence of Abuse of Divorce Authority in Islamic

Family Law I 111

koca, miktarı kadının malının üçte birini aşmayan mehri hak eder. ${ }^{87}$ Şâfiî mezhebinin genel görüşüne göre ölüm hastası kadın, aldığı mehr-i misil veya daha az bir miktar mal karşılığında hul' anlaşmasını yapabilir ve koca bunlardan birini alabilir. Hul' bedeli mehirden fazla olur ve kadın sözü edilen hastalık sonucu ölürse koca mehr-i misil miktarı kadar alabilir; fazlalık kısım için ise yabancı için yapılan vasiyette olduğu gibi mirasçıların onayına ihtiyaç vardır. İmam Şâfiî’ye göre hul' anlaşması neticesinde ayrılan eşler, biri iddet süresi içinde ölse bile birbirlerine mirasçı olamaz. Çünkü bu, bâin bir talâktır. ${ }^{88}$ Hanbelî fakîhleri ise bu konuda kocanın miras payını esas almışlardır. Onlara göre kadının, kocasının miras payı veya daha az bir miktar üzerine yaptığı hul' geçerli olur ve koca bunlardan birini alabilir. Kocanın miras payını aşan fazlalık ise geçersizdir. ${ }^{89}$ Mâlikî fakîhler, ölüm hastalığı sırasında yapılan hul' anlaşmasını caiz görmemekle beraber bunun gerçekleşmesi takdirde geçerli olduğuna hükmederler. Onlar, ölüm hastalığı sırasında hul' anlaşması neticesinde ayrılan eşlerin, birbirlerine mirasçı olamayacaklarını savunurlar. Hul' bedeli konusunda ise Hanbelî mezhebiyle aynı görüşü paylaşırlar. ${ }^{90}$

Konuyu bütüncül bir bakış açısıyla ele aldığımızda şöyle bir tabloyla karşılaşıyoruz: Ölüm hastası kadın tarafından hul'un gerçekleştirilmesi konusunda mirastan ziyade hul' bedeli esas alınmıştır. Yukarıda ana hatlarıyla temas ettiğimiz üzere fukahânın buna dair genel tutumu, kocaya hul' bedelinden, terekenin üçte birinden veya mirastan en az olanın ödenmesi gerektiği şeklindedir. ${ }^{91}$ Ancak hemen belirtmemiz gerekir ki ölüm hastası kadın, hul' anlaşmasını bir zorunluluktan dolayı gerçekleştirmiş olabileceği gibi eşini mirastan mahrum etmek veya hul' bedelini yüksek tutup mirasçllarını zarara uğratmak maksadıyla da yapmış olabilir. İkinci ihtimal hayli yüksek olduğundan bu konuda

87 'Alâüddîn Muhammed b. Ali el-Haskefî, ed-Dürrü'l-muhtâr şerḥu Tenvîri'l-ebșâr ve câmi'i'l-bihâar, thk. Abdulmün'im Halîl İbrahim (b.y.: Dâru'l-Kütübi'l-'İlmiyye, 1423/2002), 237.

88 Şâfiî, el-Ümm, 5/214-215; Şirbînî, Mugini'l-muhtâç, 4/434.

89 İbn Kudâme, el-Muggnn̂, 7/356.

90 Muhammed b. Ahmed ed-Derdîrî, eş-Şerhi'l-kebîr (b.y.: Dâru'l-Fikr, ts.), 2/354; 'Alîş, Menhu'l-celîl, 4/19.

91 Şirbînî, Muggni'l-muhtâç, 4/434; İbn 'Âbidîn, Reddü'l-muhtâr, 3/460 
112 | M. A. YAŞAR / İslâm Aile Hukukunda Boşanma Yetkisinin Kötüye Kullanılmasının Hükmü ve Hukukî Sonucu

kadının hul' hakkını kötüye kullanmasını önlemek amacıyla, maksadının tam aksine caydırıcı bir hüküm koymanın daha isabetle olacaktır. Buna göre kadının, mirasçılarını zarara uğratmak amacıyla hul' bedelini yüksek tutup kocasına iltimas geçilmesi durumunda onun amacına aykırı olarak kocaya, mirastan veya hul' bedelinden en az olanın verilmesi; buna karşı kadının, kocasını mirastan mahrum bırakmak gayesiyle hul'u gerçekleştirmesi takdirde yine kadını bu kötü niyetine karşılık olarak cezalandırmak amacıyla kocaya, belirlenen hul' bedelinden veya mirastan fazla olanın ödenmesi daha isabetli olacaktır. ${ }^{92}$ Zira bu konuda hükmün belirlenmesinden temel amaç, kadını meşru olmayan maksadına karşılık bir müeyyide uygulamak suretiyle cezalandırarak bu gibi kötü maksatlardan vazgeçirmektir.

\section{3. Ölüm Hastası Kadının Tefvîz Yöntemiyle Kocasından} Ayrılmasının Hukukî Sonucu

Tefvîz kelimesi sözlükte bir işte birisini yetkilendirmek anlamına gelmektedir.93 Fikhî bir terim olarak değişik konularda kullanılmaktadır. ${ }^{94}$ İncelememize konu olan boşanmayla ilgili tefvîzin şu tanımı yaygındır: "Kocanın boşama yetkisini eşiyle paylaşmasıdır." 95 Kullanılan söz itibariyle sarih ve kinayeli tarzında iki kısma ayrılan tefvîzin sarih kısmına talâk kelimesi; kinayeli kısmına ise hem boşanma hem de başka manalara hamledilebilen "نخيير/serbestlik, أمركك بيداكك /emrin senin elinde ve مشيئة/dileme" lafızları örnek gösterilmektedir. Kinayeli lafızlar ancak boşanma niyetiyle beraber kullanılırsa geçerlilik kazanır. ${ }^{96}$

92 Kadının ölüm hastalığı sırasında böyle bir sözleşmeye tevessül etmesi, kötü niyetinin göstergesidir. Kocanın hul' sözleşmesini kendi rızasıyla veya rızası dışında kabul etmesi durumu değiştirmez. Ayrıca kadın, kocanın zor durumda olduğu bir sırada bu sözleşmeyi dayatıp kabul ettirebileceği gibi ilgili merciiler aracılı̆̆ıyla da bunu gerçekleştirebilir. Nitekim hul'un ilk örneği olarak kabul edilen Sâbit b. Kays'ın olayında kadın, Sâbit'i sevmediği için Resûlüllah'a müracaat ederek ayrılmak istemiştir. Resûlüllah'da Sâbit'e "nikâh esnasında verdiği bahçeyi al ve onu boşa" diyerek bunu gerçekleştirmiştir. İbn Kudâme, el-Muğnî, 7/323-324.

93 İbn Manzûr, Lisânü'l-'Arab, "fvọ", 7/210.

94 Komisyon, el-Mevsû'atü'l-fikhiyye, 13/107; Abdussamet Bakkaloğlu, “Tefvîz”, Türkiye Diyanet Vakfi İslâm Ansiklopedisi (Ankara: TDV Yayınları, 2011), 40/310.

95 Şirbînî, Muggni'l-muḥtâç, 4/465; İbn 'Âbidîn, Reddü'l-muhtâr, 3/315.

96 Şirbînî, Muğni'l-muḥtâç, 4/465-468; İbn 'Âbidîn, Reddü'l-muhtâr, 3/315-323. 
M. A. YAŞAR / The Judgment and Legal Consequence of Abuse of Divorce Authority in Islamic Family Law | 113

Kadına tefvîz edilen boşanma yetkisinin geçerlilik süresi, anlaşmada kullanılan sıygalara bağlı olarak farklılık arz etmektedir. Buna göre anlaşmada tefvîz, herhangi bir zaman dilimiyle kayıtlanmadan mutlak biçimde kullanılırsa fukahânın çoğunluğuna göre kadının boşanma yetkisi anlaşmanın yapıldığı meclisin dağılmasıyla; belli bir zaman aralığını ifade eden bir siygayla sinırlandırılırsa belirlenen zaman dilimiyle sınırlı tutulur. Buna karşı tefvîz anlaşmasında bütün zamanları kapsayan geniş bir sıyga kullanılırsa herhangi bir süre kısıtlanması olmaksızın kadın istediği vakitte ayrılma yetkisini kullanabilir. ${ }^{97}$

Hanefî mezhebi, tefvîz anlaşmasını temlik/mülkiyet devri çerçevesinde değerlendirerek temlik sözleşmesinde olduğu gibi kocanın bunu eşine devretmesiyle tefvîz yetkisinin gerçekleştiğini; dolayısıyla da kocanın bundan vazgeçme hakkının olmadığını ve kadın istediği zaman bu yetkiyi kullanmaya sahip olduğunu belirtmiştir. ${ }^{98}$ Cedîd görüşünde tefvîz işlemini temlik olarak gören Şâfiî, kadının bu yetkiyi kendisine devredilmesinden hemen sonra kullanması gerektiğini, aksi takdirde kocanın bundan cayabileceğini ifade etmiştir. ${ }^{99}$ Mâlikî fakîhleri tefvîzin tevkîl, temlîk ve tahyîr tarzında üç farklı şekilde gerçekleşebileceğini; bunlardan sadece birincisinde kocanın rücû hakkı bulunduğunu savunmuşlardır. ${ }^{100}$

Mahiyet itibariyle bir çeşit boşanma olması hasebiyle evlilik birlikteliğini güçleştiren haklı bir sebep ortaya çıkmadıkça kadının tefvîze başvurması caiz görülmemelidir. Ancak ister haklı bir sebep bulunsun veya bulunmasın ilgili şartlar çerçevesinde kadının tefvîz yöntemiyle eşinden ayrılması geçerli olarak kabul edilmektedir. Bunda ittifak vardır. ${ }^{101}$ Buna göre eşlerin sağlıklı olduğu bir zamanda tefvîz

97 Derdîrî, eş-Şerhü̈l-Kebîr, 2/412; İbn 'Âbidîn, Reddü'l-muhtâr, 3/315-317; Komisyon, elMevsû'atü'l-fikhiyye, 13/112-113.

98 İbn 'Âbidîn, Reddü'l-muhtâr, 3/316.

99 Şirbînî, Mugigni’l-muhtâç, 4/466

100 Derdîrî, eş-Şerhü̈l-kebîr, 2/405.

101 Şirbînî, Muggni'l-muhtâç, 4/465; Menderes Gürkan, “İslam Aile Hukukunda Karıya Tanınan Boşama Yetkisi: Tefvizü't-Talak", İslam Hukuku Araştırmaları Dergisi 18 (2011), 281-282; Ali Yüksek, "İslam Aile Hukukunda Boşama Yetkisi ve Kadının Boşanması", Uluslararası Sosyal Araştırmalar Dergisi 7/32 (2014), 343-347. 
114 | M. A. YAŞAR / İslâm Aile Hukukunda Boşanma Yetkisinin Kötüye Kullanılmasının Hükmü ve Hukukî Sonucu

boşanması gerçekleşir ve iddet bitmeden onlardan birisi vefat ederse birbirlerine mirasçı kılınır. Buna mukabil iddetin bitmesiyle evlilik bağı son bulduğu için birbirlerine mirasçı kılınamaz. Tefvîz talâkını yapan ölüm hastası kadından önce kocası vefat ederse bu durumda iddet bitmemiş olsa bile kadın mirasçı kılınmaz. Çünkü kadın, bu hakkını kullanmakla bir anlamda mirastan vazgeçmiş sayılır. Fakat tefvîz boşanmasını gerçekleştiren kadın kocasından önce ölür ve boşanma kocanın rızası dışında yapılmışsa bu durumda her hâlükârda kocanın mirasçı kılınması daha isabetli olur. ${ }^{102}$ Nitekim kadının ölüm hastalığı içerisinde yaptığı boşamanın amacının kocasını mirastan mahrum etmek olması hayli yüksek bir ihtimaldir. Dolayısıyla bu durumda kadının amacına aykırı olarak onu cezalandırmak amacıyla kocanın mirasçı kılınması daha doğru olacaktır. Zira bu tür olaylarda hükmün konulmasında gözetilen temel hedef, ölüm hastalığı süresinde yapılan normal boşanmada olduğu gibi kadından sadır olan bu tarz kötü niyetlerin karşılıksız bırakılmaması ve dolaysıyla da meşru bir hakkın kötüye kullanılmasının önüne geçilmesidir. Bu yüzden bu türden durumlarda normal boşanmaya terettüp eden hükümler değil, sözün ettiğimiz amaca uygun hükümler uygulanmalıdır. Aynı şekilde kadının ölüm hastalığı içerisinde kocasının usûl veya füruuyla cinsel ilişkide bulunarak veya İslâm dininden çıkarak ya da mahkeme kararıyla nikâhını feshettirerek nikâh bağını bitirmesi, kocasını mirastan mahrum etmeye yönelik yüksek bir ihtimal olduğundan aynı hükme tabi tutulmalıdır. ${ }^{103}$

\subsection{Meşru Bir Sebep Olmadan Gerçekleşen Boşanmanın Hukukî Sonucu}

Yukarıda ifade edildiği üzere herhangi bir haklı gerekçe olmaksızın, başka bir evliliği gerçekleştirmek gibi önemsiz bir nedenle kocanın eşini boşaması veya kadının kendisine tanınan haklarla kocasından ayrılması tasvip edilmemiştir. Yine kimi fukahâ, asıl itibariyle boşanmayı mubah bularak bu tür ayrılmayı, caiz görmüş olsa da boşanmayı esas itibariyle haram görüp bunu, haram bulanların ${ }^{104}$ görüşünü daha tercihe şayan bulduğumuzu da belirtmiştik. Zikri geçen

\footnotetext{
102 Zuhaylî, el-Fıkhü'l-İslâmî, 9/6980-6981.

103 Zuhaylî, el-Fıkhü'l-íslâmî, 9/6981.

104 İbn 'Ẩbidîn, Reddü'l-muhtâr, 3/227; Ebû Zehra, el-Ahvâlü'ş-şahṣiyye, 285.
} 
M. A. YAŞAR / The Judgment and Legal Consequence of Abuse of Divorce Authority in Islamic

Family Law | 115

boşanmaya terettüp eden hukukî sonucun konusu, klasik dönem fıkıh kaynaklarında doğrudan ele alınmamıştır. Pozitif hukukun konuyu ele almasıyla birlikte muasır âlimler de ona eğilim göstermişlerdir. Sözü geçen âlimler, bu konuda iki farklı görüş belirtmektedirler.

a) Muasır âlimlerden bir kısmı, geçerli bir neden bulunmaksızın sırf şahsî bir menfaat uğruna gerçekleşen boşanmayı hakkın kötüye kullanılması olarak niteleyip bu çerçevede değerlendirmektedir. ${ }^{105} \mathrm{Bu}$ görüşü savunanlar, böyle bir boşanmayı haram görmekle beraber gerçekleşmesi halinde geçerli kabul etmektedirler. Buna göre kocanın boşanma yetkisini kötüye kullanarak gerçekleştirdiği bu gibi boşanma sonucunda kadının bedenine, malına veya haysiyetine bir zarar gelirse bundan koca sorumlu tutulur ve bu zarar kendisine tazmin ettirilir. Hukuk düzenlemeleri İslâm hukukuna dayalı Müslüman ülkelerinin bir kısmı bu görüşü esas almakta ve böylesi bir zarara sebebiyet veren kocayı, ta'vîz/tazminat diye ifade ettikleri bir bedelle yükümlü tutmaktadır. ${ }^{106}$ İslâm ceza hukukun ta'zîr kısmından addedilen bu gibi tazminatın miktarı ise ilgili hâkimin inisiyatifine bırakılmaktadır. Boşanan kadının emsallerine ödenen üç yıllık nafakanın miktarını aşmamak kaydıyla hâkim, oluşan zararın boyutunu dikkate alarak bu miktarı belirleme yetkisine sahiptir. Hâkim, tarafların durumuna bağlı olarak tek seferde veya taksitlendirerek aylık şeklinde bunun ödenmesine hükmedebilmektedir. Kimi muasır hukukçular, bu tazminatı "müt'atü't-talâk" olarak isimlendirilen nikâhtan sonra temas olmadan boşanan kadına verilen maddî desteğe ${ }^{107}$ kıyas ederek meşru olduğuna hükmetmişlerdir. ${ }^{108}$

105 Zuhaylî, el-Flkhü̈l-İslâmî, 9/7065.

106 Bk. Nihat Dalgın, "İslam Hukuku Açısından Boşanmanın Sonuçlarından Maddi Tazminat Üzerine Bir Değerlendirme", Ondokuz Mayıs Üniversitesi İlahiyat Fakültesi Dergisi 18-19 (2005), 39-46

107 Bk. İbrahim Kâfi Dönmez, "Mut'a”, Türkiye Diyanet Vakfı İslâm Ansiklopedisi (Ankara: TDV Yayınları, 2011), 32/174.

108 Zuhaylî, el-Fıḳhü'l-İslâmî, 9/7066; Ebû Zehra, el-Aḥvâlü'ş-şahșiyye, 285; Nuri Kahveci, "Boşanma Sonucu Manevi Tazminat Olgusuna İslam Aile Hukuku Açısından Bir Yaklaşım”, Kahramanmaraş Sütçü İmam Üniversitesi İlahiyat Fakültesi Dergisi 3/5 (2005), 101-107; 'Itrî, et-Ta'assuf fi't-țalâk, 31. 
116 | M. A. YAŞAR / İslâm Aile Hukukunda Boşanma Yetkisinin Kötüye Kullanılmasının Hükmü ve Hukukî Sonucu

b) Muasır âlimlerin bir kısmı ise boşamayı asıl itibariyle mubah bir tasarruf olarak görerek böyle bir boşanmanın meşru olduğunu, dolayısıyla da bunu yapan kocanın herhangi bir tazminatla veya malî külfetle yükümlü tutulamayacağını ileri sürmektedir. Ebu Zehra (öl. 1394/1974) bunu şöyle anlatmaktadır:

“Konuya ilişkin mahkemelerin çoğunun karar kıldığı hüküm, böyle bir boşanmada kocanın tazminatla yükümlü tutulmamasıdır. Bu, İslâm'ın temel ilkelerine uygun düşen sahîh bir karardır. Fakat bunu, 'talâkta aslolan mubahlıktır' tarzındaki hükümle gerekçelendirmeleri doğru değildir. Bilakis talâkta aslolan haramlık olup ancak haklı bir gerekçeye binaen helal kılınabilir. Bu tür gerekçeler ise genellikle psikolojik bir rahatsızlık veya hâkimler huzurunda tartışılamayacak nitelikte olup gizlenmesi gereken durumlardandır. Zaten eşler arasında cereyan eden bu gibi durumların hemen hepsi bu kabildendir. Dolayısıyla tazminatı gerekli görenler yanılmışlardır. Zira ifade ettiğim gibi eşler arasında cereyan eden olaylar her zaman açıkta söylenemeyeceği için ispat edilmeyebilir. Bu nedenle söz konusu tazminatın gerekliliğini buna bina etmeleri tasvip edilmemektedir."109

Gördüğümüz kadarıyla bu görüşün temellendirilmesinde genellikle şu gerekçelere başvurulmaktadır: a) Boşanma şâri' tarafından kocaya tanınan bir yetkidir. Bu yetkinin kullanılması hakkın kötüye kullanılması olarak değerlendiremeyeceğinden ne engellenebilir ne de koca ondan ötürü bir bedelle yükümlü tutulabilir. b) İslâm'da boşanma sonucunda kocaya, müeccel mehir, iddet nafakası ve bazı durumlarda mut'a dışında her hangi bir bedel yüklenmemiştir. c) Boşanmanın kötüye kullanılıp kullanılmadığı hususunun tespiti zordur. Çünkü bunun tespiti karı-koca arasinda cereyan eden hadiselerin bilinmesine bağlıdır. Bu hadiseler ise genellikle mahkemeler önünde açıklanamayan durumlardan oluşmaktadır. Bu yüzden boşanmanın cevazı bununla münhasır kılınmamalıdır. ${ }^{110}$

Geçerli bir neden olmadan yaptığı boşanmadan ötürü kocanın tazminata mahkûm edilmesini savunan görüşün hakkaniyete daha uygun düşeceği kanaatindeyiz. Nitekim bu hükümle mağdur kadının hakkı korunmuş olur ve bu hüküm, kötü niyet sahibi başka kocaları da caydırır. Aynı zamanda sözü edilen hüküm toplumda keyfî boşanmaları engelleyeceği için siyaset-i şer îyyenin temel hedefleri arasında yer alan

109 Ebû Zehra, el-Ahvô̂lü'ş-şahșiyye, 285; Debbâğ, "et-Ta'assuf fi'ț-țalâḳ”, 88.

110 Debbâğ, "et-Ta'assuf fi'ț-țalâḳ”, 88; Sümeyye, Tațbîku naẓariyyeti't-ta'assuf, 70. 
ailelerin dağılmasının ve dolayısıyla da toplumda bozulmanın önüne de geçilmiş olur. Ancak böyle bir hükmün, boşanan kadının maddî veya manevî bir zarara uğradığı tespit edilmesiyle sinırlı tutulması istismar edilmemesi açısından daha isabetli olacaktır. Karşıt görüştekilerin, boşanma koca için meşru bir hak olduğu için hiçbir şekilde engellenemez şeklindeki gerekçeleri, "meşru da olsa hiçbir hakkın başkasına zarar verme aracı kılınmayacağı" ilkesiyle reddedilir. ${ }^{111}$ Onların mehir, nafaka ve bazı hallerde mut'a dışında hiçbir şeyin kocaya yüklenmediğini şeklindeki gerekçeleri normal şartlarda yapilan boşanma için geçerlidir. Bahse konumuz boşanmada başkasına zarar verme olayı söz konusu ve zikredilen tazminat, bundan ötürüdür. Aynı şekilde muhalif görüştekilerin, boşanmaya sebep olan karı ile koca arasında vuku bulan hadiselerinin tespitinin genellikle mümkün olamayacağı, dolayısıyla da boşanmanın meşruluğu bu türden olaylara bağlanamayacağ 1 tarzındaki gerekçelerine şu şekilde cevap verilebilir: Karı ile koca arasındaki ilişkiler, her zaman bilinmeyebilir ve elbette ifşa olunmaması esastır. Ancak ailenin dağılması ve kadının mağduriyeti söz konusu olduğunda sözü edilen hadislerin en azından ilgili hâkimler tarafından bilinmesi elzemdir. Bu sebeple sağlıklı bir kararın alınabilmesi için ne kadının ne de kocanın boşanmaya gerekçe olan olayları ilgili hâkimlerden gizlememeleri gerekir.

Burada belirtmemiz gereken önemli bir husus, muasır âlimlerinin ve hukukçularının genelinin konuyu kocanın tek taraflı olarak gerçekleştirdiği boşamaya münhasır kılıp kadının haklı bir gerekçe olmadan nikâh akdinin sonlandırmasına sebep olması konusuna değinmemeleridir. Her ne kadar sözünü ettiğimiz boşanma, daha çok koca tarafından yapıldığı ve bu konuda en çok mağduriyet yaşayan tarafın kadın olduğu bir gerçek olsa da kadına da hul', tefvîz ve tefrîk ${ }^{112}$ gibi boşanma/ayrılma hakları verilmiş ve erkekler kadar olmasa da kadının da bu hakları kötüye kullanması mümkündür. Hâl böyle olunca kadının gerçekleştirdiği ayrılma neticesinde kocanın zarar görmesi durumunda -boşanma kocanın rızası dışında yapılmış olmak şartıyla-

111 Zuhaylî, el-Flkhü̈l-İslâmî, 4/3229.

112 Tefrîk, kadının haklı bir gerekçe ileri sürerek mahkeme yoluyla eşinden ayrılmasıdır. H. İbrahim Acar, "Tefrîk", Türkiye Diyanet Vakfı İslâm Ansiklopedisi (Ankara: TDV Yayınları, 2011), 40/277. 
118 | M. A. YAŞAR / İslâm Aile Hukukunda Boşanma Yetkisinin Kötüye Kullanılmasının Hükmü ve Hukukî Sonucu

kadına da tazminatın ödettirilmesi daha doğru olacağı kanaatindeyiz. Zira ölüm hastalığı sırasında yapılan boşanmada olduğu gibi bu durumda da tazminat hükmünün konulmasında gözetilen temel hedef, meşru hakkın kötüye kullanılmasını önlemek ve böyle bir hataya meyilli kişileri bunu işlemekten caydırmaktır.

\section{Sonuç}

Evlilik hayatının, karı ve koca için ıstırap ve meşakkatte dönüşüp sürdürülmesi imkânsız bir hal aldığında şer î prensipler çerçevesinde yapılmak suretiyle boşanma, bir çözüm yolu olarak meşru kılınmıştır. Ancak evlilikten beklenen amaçlar elde edilip boşanmayı gerektiren herhangi bir gerekçe bulunmadığı durumlarda yapılan boşanma konusunda ise talâkta aslolan mubahlık veya haramlık olmasına bağlı olarak iki farklı görüş ortaya çıkmıştır. Kimi fukahâ, boşanmayı aslı itibarıyla meşru bir hak olarak görmüş ve buna binaen haklı bir gerekçe olmasa bile böyle bir hakkın kullanılmasında şerî̂ bir mahzurun olmadığını ileri sürmüştür. Kimi fukahâ ise boşanmanın asıl hükmü haramlık olduğunu; dolayısıyla da meşru bir neden olmadan yapılan boşanma, şâri'in maksadına aykırı olduğu gerekçesiyle hakkın kötüye kullanılması olduğunu ifade etmiş ve buna istinaden böyle bir boşanmayı haram görmüştür. Ancak süreklilik isteyen evlilik akdinden beklenen dinî ve dünyevî birçok maslahatın gerçekleştirilmesi adına zorunlu bir durum olmadıkça böyle bir akdin sonlandırılmasının haram bir tasarruf olarak görülmesi yerinde bir hüküm olacağını düşünmekteyiz. Zaten böyle bir boşanmadan çoğunlukla karşı tarafın zararı amaçlanmaktadır. Bu ise "Zarar ve zarara zararla karşılık vermek yoktur." şeklindeki şerî‘atın genel ilkesi başta olmak üzere ilgili delillerle kat'î bir biçimde haram kılınmıştır. Sözü edilen boşanma, ister koca tarafından normal boşanma yoluyla ister kadın tarafından hul' veya tefvîz yöntemiyle yapılmış olsun müsavidir.

Haklı bir gerekçe olmadan sırf karşı tarafa zarar vermek veya şahsi bir menfaat elde etmek amacıyla gerçekleşen boşanma/ayrılma bir kısım fukahâ tarafından haram bir tasarruf olarak görülse degeçerlidir. $\mathrm{Bu}$ konuda fukahâ ittifak içindedirler. Hakkın kötüye kullanılması olarak nitelendirilen böyle bir boşanmanın şu şekilleri bulunmaktadır: Ölüm hastası kocanın eşini mirastan mahrum etmek için boşaması, ölüm döşeğinde bulunan kadının kocasını mirastan mahrum bırakmak maksadıyla hul' veya tefvîz yoluyla ondan ayrılması, kocanın 
M. A. YAŞAR / The Judgment and Legal Consequence of Abuse of Divorce Authority in Islamic

Family Law I 119

veya kadının başka bir evliliğin gerçekleşmesi gibi önemsiz bir menfaat için boşanma yetkisini kullanarak evlilik akdini bitirmesi.

Ölüm hastalığı esnasında kocanın gerçekleştirdiği boşanma, eşini mirastan mahrum etmek amacıyla yapmış olması hayli yüksek bir ihtimal olduğundan böyle bir boşanmanın hakkın kötüye kullanılması olarak kabul edilip bu çerçevede değerlendirilmesi tercihe şayan bulunmuştur. Böyle bir durumda kadının mirasçı kılınması hususunda ise ihtilaf edilmiştir. Kadının mirasçılığını, iddet müddetinin bitmesiyle veya başka birisiyle evlenmesiyle sınırlandıran fakîhler olsa bile başka birisiyle evlense bile kadının mirasçllı̆ını savunan fakîhlerin görüşünü daha isabetli bulduğumuzu ifade etmek isteriz. Zira böyle bir hastalığa yakalanan kocanın, diğer mirasçılarında olduğu gibi kadının mirasçılığ kocanın hastalığıyla sabit olmaktadır. Böyle bir durumda mirasçıların haklarının korunması amaciyla kocanın bazı tasarruflarına kisıtlanma getirildiğine göre kadının da miras hakkı, iddetin bitmesiyle veya başka biriyle evlenmesiyle sinırlandırılmaması gerekir. Aynı şekilde ölüm hastalığı sırasında kadının tefvîz yöntemiyle kocasından ayrılması da hakkın kötüye kullanılması olarak değerlendirilip kocanın mirasçılığ herhangi bir durumla sinırlandırılmaması isabetli bir karar olacaktır.

Kadının hul' anlaşmasıyla kocasından ayrılması olayında iki farklı kötü niyet ihtimali bulunmaktadır. Bunlardan biri kadının bu yöntem ile mirasçılarına zarar vermek kastıyla hul' bedelini yüksek tutarak kocasını kayırmasıdır. Diğeri ise kadının kocasını mirastan mahrum etmek amacıyla böyle bir yola başvurmasıdır. Her iki durumda da kadının amacının tam aksine bir hükmün verilmesi caydırıcılık açısından önemli bir etken olacaktır. Buna binaen ilk ihtimalde kocaya hul' bedelinden, terekenin üçte birinden veya mirastan en az olanın ödenmesi; ikincisinde ise ona, hul' bedelinden veya mirastan en fazla olanın verilmesi hakkaniyete daha uygun olacaktır.

Boşanmayı gerektiren herhangi bir gerekçe olmaksızın sırf şahsî bir menfaat için kocanın eşini boşaması nedeniyle kadının maddî veya manevî bir zarara uğraması halinde -oluşan zararın boyutu dikkate alınmak suretiyle- kocaya tazminat ödettirilmesi, netice bakımından daha yararlı olacağı kanaatindeyiz. Aynı şekilde kadının hul', tefrîk veya tefvîz yoluyla gerçekleştirdiği boşanma neticesinde kocanın zarar 
120 | M. A. YAŞAR / İslâm Aile Hukukunda Boşanma Yetkisinin Kötüye Kullanılmasının Hükmü ve Hukukî Sonucu

görmesi durumunda kadına da tazminatın ödettirilmesi daha hukukî bir uygulama olacağı muhakkaktır.

Son söz olarak diye biliriz ki haklı bir gerekçe olmaksızın gerçekleştirilen boşanmanın haram bir tasarruf olarak kabul edilmesi ve bunu yapan koca veya kadın ile kötü amacının tam aksine göre muamele edilerek onlar hakkında zikredilen müeyyidelerin uygulanması, bu türden kötü niyetlere meyilli olan emsal eşler için de caydırıcı bir rol oynayacaktır. Bu nedenle ilgili makamların, İslâm hukuku tarafından öngörülen sözünü ettiğimiz hukukî sonuçları dikkate almaları boşanma oranlarını doğradın etkileyeceği kanaatindeyiz.

\section{Kaynakça}

Abdulazîz, Sümeyye. Tațbîku nazariyyeti't-téassuf fî isti'mâli'l-hak fî ba'di mesâili'l-ahvâli'ş-şahșiyye. Buyra: Câmi'atu Aklî Mohand Olhâc, Yüksek Lisans Tezi, 2016.

Acar, H. İbrahim. "Tefrîk". Türkiye Diyanet Vakfı İslâm Ansiklopedisi. 40/277-279. Ankara: TDV Yayınları, 2011.

Ahmed b. Abdulhalim İbn Teymiyye, el-Fetâve'l-kubrâ. 6 Cilt. b.y.: Dâru'l-Kütübi'l-'İlmiyye, 1408/1997.

'Alîş, Muhammed b. Ahmed. Menhư'l-celîl şerḥu Muhtașari'l-Halîl. 9 Cilt. Beyrut: Dâru'l-Fikr, 1408/1989.

Altun, Muhammed Latif. Aile Hukuku Özelinde Hanefi ve Evzââ Mezheplerinin Mukayesesi. Ankara: İlahiyat Yayınları, 2020.

Aslan, Bedri. "Boşanma Yetkisi Hakkında Yapılan Tartışmalar". Uluslararası Sosyal Araştırmalar Dergisi 11/55 (2018), 918-927.

Aslan, Mehmet Selim. "İslam Hukukunda 'Ta'assuf' Kavramı ve Hükümlere Etkisi". EKEV Akademi Dergisi-Sosyal Bilimler 20/67 (2016), 205-235.

Atar, Fahrettin. "Muhâlea". Türkiye Diyanet Vakfı İslâm Ansiklopedisi. 30/399-402. Ankara: TDV Yayinları, 2005.

'Avn, Ali Abdullah. “et-Ta'assuf fi't-ṭalâk ve'l-ḥukûküu'l-mütereteb 'aleyh”. Dirâsâtu 'Ulûmi'ş-Şerî'a ve'l-Kânûn 43/2 (2016), 643-661.

Bâbertî, Muhammed b. Muhammed. el-'inâye şerhu'l-Hidâye. 10 Cilt. b.y.: Dâru'l-Fikr, ts. 
M. A. YAŞAR / The Judgment and Legal Consequence of Abuse of Divorce Authority in Islamic Family Law | 121

Bâcî, Süleymân b. Halef b. Sa'd. el-Münteḳ̄ 7 Cilt. Misır: Matba'atü'sSa'âde, 1332/1914.

Bakkal, Ali. "Maraz-1 mevt". Türkiye Diyanet Vakfı İslâm Ansiklopedisi 28/39-41. Ankara: TDV Yayınları, 2003.

Bakkaloğlu, Abdussamet. "Tefvîz". Türkiye Diyanet Vakfı İslâm Ansiklopedisi 40/3101-311. Ankara: TDV Yayınları, 2011.

Bardakoğlu, Ali. "Ehliyet". Türkiye Diyanet Vakfı İslâm Ansiklopedisi. 10/533-339. Ankara: TDV Yayınları, 1994.

Buhârî, Muhammed b. İsmail. Șahîhu'l-Buhârî.. thk. Muhammed Züheyr. 9 Cilt. b.y.: Dâru Tavki'n-Necât, 1422/2001.

Buhûtî, Mansûr b. Yunus. Keşşâfü'l-kina' 'an metni'l-İknâ'. 6 Cilt. b.y.: Dâru'l-Kütübi'l-'İlmiyye, ts.

Cüveynî, Abdülmelik b. Abdillâh. Nihâyetü'l-matlab fî dirâyeti'l-mezheb. b.y.: Dâru'l-Minhâc, 1428/2007.

Çiftci, Adem. "Vaktinden Önce Yapılan Tasarrufların Fıkhî Hükümlere Etkisi (Aile Hukuku Özelinde)". İslam Hukuku Araştırmaları Dergisi 33 (2019), 361-390.

Dalgın, Nihat. "İslam Hukuku Açısından Boşanmanın Sonuçlarından Maddi Tazminat Üzerine Bir Değerlendirme". Ondokuz Mayıs Üniversitesi İlahiyat Fakültesi Dergisi 18-19 (2005), 35-69.

Debbâğ, Eymen Mustafa. "et-Ta'assuf fi't-ṭalâḳ". Mecelletu Câmi'atu'lAksâ 12/1 (2014), 63-101.

Derdîrî, Muhammed b. Ahmed. eş-Şerhu'l-kebîr. 4 Cilt. b.y.: Dâru'l-Fikr, ts.

Dirînî, Fethî. Nazariyyetü't-ta'assuf fî̀ isti'mâli'l-hak fi'l-fiḳhi'l-İslamî. Beyrut: Müessesetü'r-Risâle, 1408/1988.

Dönmez, İbrahim Kâfi. "Mut'a". Türkiye Diyanet Vakfi İslâm Ansiklopedisi. 32/174-180. Ankara: TDV Yayınları, 2011.

Ebû 'Abdû, Şîrîn Zuheyr. Ma'âlimü'l-üsreti'l-muslime fi'l-Kur'ani'l-Kerîm. Gazze: el-Câmi'atü'l- İslâmiyye, Yüksek Lisan Tezi, 1430/2010.

Ebû Dâvûd, Süleyman b. el-Aş'as. es-Sünen. 4 Cilt. Beyrut elMektebetü'l-'Asriyye, ts.

Ebû Zehra, Muhammed. el-Ahvâlü'ş-şahsiyye. Kahire: Dâru'l-Fikri'l'Arabî, ts. 
122 | M. A. YAŞAR / İslâm Aile Hukukunda Boşanma Yetkisinin Kötüye Kullanılmasının Hükmü ve Hukukî Sonucu

Gürkan, Menderes. "İslam Aile Hukukunda Karıya Tanınan Boşama Yetkisi: Tefvîzü't-Talak". İslam Hukuku Araştırmaları Dergisi 18 (2011), 275-310.

Hallâf, Abdulvehhâb. Ahkâmü'l-ahvâli'ş-şahșiyye fi'ş-şerî̀ati'l-i̇slâmiyye. Kahire: Dâru'l-Kütübi'l-Misriyye, 1357/1938.

Haskefî, 'Alâüddîn Muhammed b. Alî. ed-Dürrü'l-muhtâr şerhu Tenvîri'lebșâr ve câmi'i'l-bihâr. thk. Abdulmün'im Halîl İbrahim. b.y.: Dâru'l-Kütübi'l-'Illmiyye, 1423/2002.

Hattâb, Muhammed b. Muhammed er-Ru'înî. Mevâhibü'l-celîl fî şerḥi Muhtașari Halîl. 6 Cilt. b.y.: Dâru'l-Fikr, 1412/1992.

Haydar Efendi, Ali. Dürerü'l-hükkâm şerhu Mecelleti'l-ahkâm. 4 Cilt. b.y.: Dâru'l-Cîl, 1411/1991.

'Itrî, Muhammed. et-Ta'assuf fi'ț-ṭalâk fi't-teşrî̀i'l-Cezâirî. Celfe: Câmi'atu Ziyân 'Âşûr, Yüksek Lisans Tezi, 2016.

İbn 'Âbidîn, Muhammed Emîn b. Ömer. Reddü'l-muhtâr 'ale'd-dürri'lmuhtâr ve hâş̧iyeti İbn 'Âbidîn. 6 Cilt. Beyrut: Dâru'l-Fikr, 1412/1992.

İbn Battâl, Ali b. Halef. Şerhu Șahîhi'l-Buhârî. thk. Ebû Temîm Yâsir b. İbrahim. 10 Cilt. Riyad: Mektebetü'r-Rüşd, 1423/2003.

İbn Kudâme, Abdullah b. Ahmed. el-Kâfi fi fikhi'l-imâm Ahmed. 4 Cilt. b.y.: Dâru'l-Kütübi'l-'İlmiyye, 1414/1994.

İbn Kudâme, Abdullah b. Ahmed. el-Muginnt. thk. Abdullah b. Abdilmuhsin - Abdulfettah Muhammed. 10 Cilt. Riyad: Dâru 'Âlemi'l-Kütüb, 1406, 1412, 1417/1986, 1992, 1997.

İbn Mâce, Ebu Abdillâh Muhammed. es-Sünen. 2 Cilt. b.y.: Dâru İhyâi'lKütübi'l-'Arabî, ts.

İbn Manẓûr, Muhammed b. Mukrim. Lisânü'l-'arab. 15 Cilt. Beyrut: Dâru Sadr, 1414/1994.

İbn Münzir, Muhammed b. İbrahim. el-İşrâf alâ mezhebi'l-'ulemâ. thk. Sağîr Ahmed. 10 Cilt. b.y.: Mektebetu Mekke es-Sikâfiyye, 1425/2004.

İbn Rüşd, Muhammed b. Ahmed el-Cedd. el-Mukaddimâtü'l-mümehhidât. thk. Muhammed Hacî. 3 Cilt. Beyrut: Dâru'l-Garbi'l-İslâmî, 1408/1988.

İşbîlî, Muhammed b. Abdillâh. el-Mesâlik fî şerhịi Muvaț̣a' Mâlik. 8 Cilt. b.y.: Dâru'l-Garbi'l-İslâmî, 1428/2007. 
M. A. YAŞAR / The Judgment and Legal Consequence of Abuse of Divorce Authority in Islamic Family Law | 123

Kahveci, Nuri. "Boşanma Sonucu Manevi Tazminat Olgusuna İslam Aile Hukuku Açısından Bir Yaklaşım”. Kahramanmaraş Sütçü İmam Üniversitesi İlahiyat Fakültesi Dergisi 3/5 (2005), 89-113.

Kanâzi'î, Abdurrahman b. Mervân. Tefsîru'l-Muvatṭa'. thk. 'Âmir Hüseyin Sabrî. 2 Cilt. Katar: Dâru'n-Nevâdir, 1429/2008.

Kârî, Ali b. Muhammed. Mirkâtü'l-mefâtih şerḥu Mişkâti'l-meșâbîh. 9 Cilt. Beyrut: Daru'l-Fikr, 1422/2002.

Kâsânî, Âlâüddîn Ebû Bekir b. Mes'ud. Bedâi'u'ș-șanâi' fî tertibi'ş-şerâi'. 7 Cilt. b.y.: Dâru'1-Kütübi'l-'İlmiyye, 1406/1986.

Kerîm, Fârûk Abdullah. el-Vesît fî şerhi kânûni'l-ahvâali'ş-şahșiyye el-Irâkî. Süleymaniye: Câmi'atü's-Süleymaniyye, 2004.

Komisyon, el-Mevsûatü'l-fikhiyyetü'l-Kuveytiyye. 45 Cilt. Kuveyt: Dâru'sSelâsil, 1427/2006.

Kurtubî, Muhammed b. Ahmed. el-Câmi' li ahkâmi'l-Kur'an. thk. Ahmed el-Berdûnî - İbrahim Etfîş. 20 Cilt. Kahire: Dâru'l-Kütübi'lMisriyye, 1384/1964.

Kurtubî, Yusuf b. Abdullah b. Muhammed b. Abdilberr. el-İstizkâr. thk. Sâlim Muhammed 'Atâ-Muhammed Ali Mu'avviz. 9 Cilt. Beyrut: Dâru'1-Kütübi'l-'İlmiyye, 1421/2000.

Makdisî, Abdurrahmân b. Muhammed b. Ahmed. eş-Şerhu'l-kebîr 'alâ metni'l-Mukni'. 12 Cilt. b.y.: Dâru'l-Kütübi'l-'Arabiyye, ts.

Mâlik b. Enes. el-Müdevvene. 4 Cilt. b.y.: Dâru'1-Kütübi'l-'İlmiyye, 1415/1994.

Mâverdî, Ali b. Muhammed. el-Hâvi'l-kebîr fî fikhi'l-imam eş-Şâfî̀. 19 Cilt. Beyrut: Dâru'l-Kütübi'l-'İlmiyye, 1419/1999.

Nevevî, Yahya b. Şeref. Ravdatü't-țalibîn ve 'umdetü'l-müftîn. thk. Zuhayr eş-Şâvîş. 12 Cilt. Beyrut: el-Mektebü'1-İslâmî, 1412/1991.

Râzî, Fahruddîn Muhammed b. Ömer. Mefâtihu'l-ġayb (et-Tefsîru'l-kebîr). 32 Cilt. Beyrut: İhyâü't-Türâsi'1-'Arabî, 3. Basım, 1420/1999.

Remlî, Muhammed b. Ahmed Şihâbüddîn. Nihâyetü'l-muhtâc ilâ şerhi'lMinhâc. 8 Cilt. Beyrut: Dâru'l-Fikr, 1404/1984.

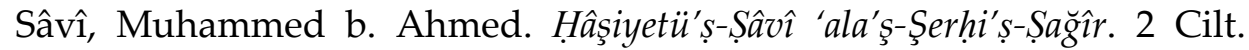
b.y.: Mektebetu Mustafa'l-Bâbi'l-Halebî, 1372/1952.

Serahsî, Ebû Bekr Muhammed b. Ebî Sehl. el-Mebsûtt. 30 Cilt. Beyrut: Dâru'l-Ma'rife, 1414/1993. 
124 | M. A. YAŞAR / İslâm Aile Hukukunda Boşanma Yetkisinin Kötüye Kullanılmasının Hükmü ve Hukukî Sonucu

S,eybânî, Ahmed b. Muhammed b. Hanbel. el-Müsned. thk. Şuayb elArnavutî vd. 50 Cilt. b.y.: Müssesetü'r-Risâle, 1421/2001.

Şâfiî, Muhammed b. İdrîs. el-Ümm. 6 Cilt. Beyrut: Dâru'l-Ma'rife, $1410 / 1490$.

Şevkânî, Muhammed b. Ali. Neylü'l-evtâr. thk. İsâmüddîn es-Sabâbitî. 8 Cilt. Misır: Dâru'l-Hadîs, 1413/1993.

Şeybânî, Muhammed b. el-Hasen b. Ferkad. el-Aṣl. thk. Muhammed Boynukalın. 12 Cilt. Beyrut: Dâru İbn Hazm, 1433/2012.

Şeybânî, Muhammed b. Hasen. el-Hucce 'alâ ehli'l-Medîne. 4 Cilt. Beyrut: 'Âlemü'l-Kütüb, 1403/1983.

Şirbînî, Muhammed b. Ahmed. Muginni'l-muhtâç ilâ ma 'rifeti maâni elfâzi'lMinhâc. 6 Cilt. Beyrut: Dâru'l-Kütübi'l-'İlmiyye, 1415/1994.

Yılmaz, İbrahim. "İslâm Aile Hukukunda Boşanmaları Önleyici Bir Tedbir Olarak Tahkîm Müesseselerine Hukuki İşlerlik Kazandırılması". Turkish Studies, 12/10 (2017), 329-360.

Yiğit, Metin. "İslam Hukuku'nda Boşanmayı Önleyici Tedbirler". Dicle Üniversitesi İlahiyat Fakültesi Dergisi 19/1 (2017), 1-20.

Yüksek, Ali. "İslam Aile Hukukunda Boşama Yetkisi ve Kadının Boşanması". Uluslararası Sosyal Araştırmalar Dergisi 7/32 (2014), 340-354.

Zeydân, Abdulkerîm. el-Mufașal fî ahkâmi'l-mer'e ve'l-beyti'l-müslim fi'şşerî'ati'l-İslâmiyye. 11 Cilt. Beyrut: Müessesetü'r-Risâle, 1413/1993.

Zeylaî, Osman b. Ali. Tebyînü'l-hekâik şerhu Kenzi'd-dekâik. 6 Cilt. Kahire: el-Matb'atu'l-Emîriyye el-Kübrâ, 1313/1896.

Zuhaylî, Vehbe b. Mustafa. el-Flḳhü'l-İslâmî ve edilletühu. 10 Cilt. Dımaşk: Dâru'l-Fikr, ts. 